Article

\title{
Genetic Diversity of Fusarium oxysporum f. sp. cubense Causing Panama Wilt of Banana in the Philippines
}

\author{
Kristle Grace I. Aguilar-Hawod ${ }^{1}$, Fe M. de la Cueva ${ }^{2}$ and Christian Joseph R. Cumagun ${ }^{1,3, *(D)}$ \\ 1 Institute of Weed Science, Entomology and Plant Pathology, College of Agriculture and Food Science, \\ University of the Philippines Los Baños, Los Baños 4031, Laguna, Philippines; kristle.hawod@stk-ag.com \\ 2 Institute of Plant Breeding, College of Agriculture and Food Science, University of the Philippines Los Baños, \\ Los Baños 4031, Laguna, Philippines; fmdcueva@yahoo.com \\ 3 Molecular Phytopathology and Mycotoxin Research, University of Göttingen, Grisebachstrasse, \\ 637077 Göttingen, Germany \\ * Correspondence: ccumagu@uni-goettingen.de
}

Received: 29 November 2019; Accepted: 24 December 2019; Published: 28 December 2019

\begin{abstract}
Panama wilt, caused by Fusarium oxysporum f. sp. cubense (Foc) is considered one of the most devastating banana diseases in recorded history. The disease threatens the banana industry due to Tropical Race 4 (TR4) infecting the Cavendish cultivar. Forty-two of the 45 representative isolates from Luzon were pathogenic, based on leaf symptom index and vascular discoloration rating. Accurate, fast and reliable identification are pre-requisites for effective management considering there are yet no proven effective chemicals to control the disease, thus the confirmation by a PCR-based diagnostic tool is essential. Using race-specific primers, FocTr4-F/FocTr4-R and Foc-1/Foc-2, the absence of TR4 in Luzon has been confirmed, however, the occurrence of Race 4 has been reported, which should also be taken in consideration as the latter can also cause severe damage under favorable conditions. Furthermore, to examine genetic diversity of Foc in bananas, 55 of the 164 isolates collected from Regions I, II, III, IV and Cordillera Administrative Region (CAR) were analyzed by fingerprinting techniques using M13, ERIC and REP primers. Twenty-two reference isolates from Mindanao were also analyzed using the same primers. Foc isolates were differentiated into two clades at $25 \%$ similarity level, classifying all Mindanao isolates to clade A. Consistently high genetic variation was obtained from Luzon isolates using M13, an arbitrarily primed fingerprinting technique and repetitive elements, REP and ERIC-PCR, while low genetic variation was obtained from Mindanao isolates. ERIC-PCR was the most informative and predictive fingerprinting method as the TR4 isolates from Mindanao were grouped together. No grouping of Foc isolates was observed with respect to geographical origin, except isolates from Mindanao. In addition, grouping of Foc4 is also regardless of host variety in all analyses conducted. Overall, high genetic variability was recorded in Foc Philippine population for the three primers used, which might render host resistance vulnerable.
\end{abstract}

Keywords: Fusarium oxysporum pv. cubense; genetic diversity; Luzon; Panama Wilt; Tropical Race 4

\section{Introduction}

Banana is second in world fruit production after oranges. It is a vital source of income, employment and export revenues for exporting countries, which are mostly developing countries in Latin America, Southeast Asia and Africa [1]. It is also the fifth most important agricultural crop in world trade [2]. In the Philippines, banana is one of the country's top export crops, thus considered the most important fruit crop in the country in terms of volume of production and export earnings [3]. The Philippines ranked fifth among the top producing countries of banana, next to India, Ecuador, Brazil and China, 
respectively. In terms of exports, it ranked third after India and Cost Rica [4]. The total volume of production in 2012 reached 9.2 M metric tons, of which 4.7 M metric tons are Cavendish bananas for export, mainly grown in Mindanao [5].

Several diseases hinder global production, which include Sigatoka or black leaf streak disease caused by Mycosphaerella fijiensis and Panama disease or Fusarium wilt caused by Fusarium oxysporum $\mathrm{f}$. sp. cubense (Foc) [6,7]. Fusarium wilt of banana caused by the soil-borne fungus Fusarium oxysporum Schlechtend: Fr. f. sp. cubense (E.F. Smith) Snyder \& Hansen-Foc, was first reported in Australia in 1874, and as early as 1890 caused an epidemic in Panama, Thus it became known as the Panama disease $[7,8]$. The disease reached such epidemic proportions that it was considered one of the most destructive plant diseases in recorded history. Panama disease is now found in all banana-producing regions, except the islands in the South Pacific, the Mediterranean, Melanesia, and Somalia [9-11]. The presence of resting spores, also known as chlamydospores, make it possible for the pathogen to survive successfully without its host for as long as 30 years, thus susceptible varieties cannot be planted in infested soils for decades [7,12]. In effect, Gros Michel, the previously favored variety for world trade, was wiped out by Fusarium wilt in the middle of the last century forcing the trade to shift to resistant cultivars of the Cavendish subgroup (AAA). The Cavendish cultivar solved the problem for a while; however, in the 1990s, it became susceptible to a virulent strain of Panama wilt, named Race 4 found in Asia. Though in Taiwan, the disease was recorded as early as 1967, the destructiveness of the disease in banana plantations in Indonesia and Malaysia was noted in the early 1990s [12]. To differentiate isolates infecting Cavendish bananas in the tropics and subtropics, Race 4 is further subdivided in Tropical Race 4 (TR4) and Subtropical Race 4 (ST4), respectively $[13,14]$. While ST4 pathogenicity is enhanced by abiotic stress, TR4 is pathogenic under tropical and subtropical conditions and therefore deemed more aggressive [11,15].

Unlike Sigatoka, which is also a major constraint of production in banana plantains, Fusarium wilt cannot be controlled by fungicides and therefore continues to be a major threat to banana production. Being the country's biggest export-earning horticultural crop, losses in the banana industry brought about by the destructive Panama disease will likely negatively affect the national economy. In addition, as the disease infects local banana varieties like Latundan, Lakatan and Senorita, small-scale local banana producers will also be affected. Quarantine measures are in effect to control the spread of the disease from the Cavendish plantains in Mindanao to other parts of the country. Thus, a fast and accurate diagnostic procedure is of immense importance to effectively implement these quarantine measures.

There are only a few studies on genetic diversity of Foc in the Philippines [16,17]. Knowledge of the diversity of the pathogen population in specific geographical locations will not only help select Foc-resistant banana cultivars, but may possibly determine the duration of resistance [18]. Most importantly, it will help in the development of appropriate disease management strategies, particularly setting up quarantine measures to prevent spread to new locations, especially in the absence of effective control. Molecular markers have proven effective and are more accurate than phenotypic characterization. Arbitrarily primed PCR technique, such as Random Amplified Polymorphic DNA (RAPD). Used in combination with amplification of the repetitive elements in the genome can be used to characterize diversity of closely related species. The M13 primer has been widely used for fingerprinting a wide variety of filamentous fungi discriminating closely related isolates of a single species, becoming a 'universal probe' [19]. Short oligonucleotides such as Enterobacterial Repetitive Intergenic Consensus (ERIC)-PCR, Repetitive Extragenic Palindromic (REP) and BOX Elements initially obtained from prokaryotes, amplify highly conserved inter-repeat sequences in the genome and showed discriminative power to differentiate closely related fungal species [20-22].

The objectives of this study are: (1) to test the pathogenicity of representative isolates collected from different parts of Luzon; (2) to determine the occurrence of Tropical Race 4 using race-specific primers from different areas of Luzon, and (3) to examine the genetic diversity of Foc isolates from Luzon and Mindanao using M13, ERIC, REP and BOX primers. 


\section{Materials and Methods}

\subsection{Survey and Collection of Foc}

The presence of Fusarium wilt in bananas was surveyed in representative provinces from Regions I, II, III, IV and Cordillera Administrative Region (CAR). Different varieties (Lakatan, Latundan and Saba) were examined for typical wilting symptoms starting from the leaf margin of older leaves extending to the midrib. Pseudostems were then observed for splitting, and an initial cut on a small portion was done to examine discoloration. Samples were collected as pseudostem strands, labeled and placed in separate containers.

\subsection{Morphological Identification and Maintenance of Foc Cultures}

Samples were washed with running water and air dried before processing. Small sections $(2 \mathrm{~mm}$ $\times 3 \mathrm{~mm}$ ) from advancing regions of discoloured pseudostem strands were obtained. These tissues were surface-sterilized using 10\% sodium hypochlorite for $5 \mathrm{~min}$ and washed in three changes of sterile distilled water and grown in Potato Dextrose Agar (PDA). After 5-7 days incubation at room temperature, mycelial growth from the seeded tissues typical of a Fusarium, which are usually white, violet and magenta in color were transferred to PDA slants for purification. Isolated colonies were examined under light microscope for the appearance of macro and microconidia. Upon confirmation, cultures were maintained in Spezieller Nahrstoffarmer Agar (SNA) [23] to avoid degeneration in nutrient-rich media such as PDA. Each isolate was single-spored to ensure purity of cultures [24]. This method was done by pouring spore suspension in dry water agar (WA) plates, and its excess was shaken off immediately. Inoculated plates were incubated in the dark for 18-20 h at an inclined position $\left(30-40^{\circ}\right)$, and examined under dissecting microscope. A single germinated conidium was removed on a small square of agar using a flattened transfer needle and transferred in carnation leaf agar (CLA) to induce sporulation. Colonies that are formed after 5-10 days of incubation were transferred to SNA and PDA slants for further analyses.

Cultural and morphological characteristics were described using the techniques of Nelson et al. [25] and Leslie and Summerell [26]. Data were taken from 12-day old culture of Foc isolate in PDA. Colony color, diameter, hyphal growth, presence of sporodochia were recorded 10 days after incubation. The presence of macro and microconidia and chlamydospores were observed under light microscope.

Aside from periodic transfer of isolates for maintenance, pure culture preservation was prepared by placing sterilized filter paper discs per pure culture of an isolate in SNA slants using forceps. Filter paper discs were grown for at least one week and transferred in to Eppendorf tubes for long term storage.

\subsection{Pathogenicity Tests}

Random representative isolates from different regions of Luzon were selected for a pathogenicity test described by [27] with some modifications. Foc isolates representing each region were inoculated on 6-week-old tissue cultured from Latundan varieties, chosen for its susceptibility to different recognized races of Foc. Inoculum was prepared by transferring 7-day old isolates in sterilized corn meal-sand media. After 10 days of incubation, inoculation on plants was performed by pouring colonized media of each isolate in pots containing the test plants. This is a modification from the original method which described transferring of test plants to pots originally filled with media containing the inoculum. Furthermore, root dipping step, prior to inoculation with corn meal-sand media was also omitted. There were four replicates per isolate representing different areas of collection. During acclimatization and after inoculation, plants were maintained in the greenhouse. Data taken included aggressiveness, which was characterized by the number of days to first symptom appearance; disease severity based on external symptoms following leaf symptom index and vascular discoloration rating scale developed by International Network for the Improvement of Banana and Plantains (INIBAP) [28] with some modifications. Aggressiveness' parameters were both taken during destructive sampling at 45 days 
after inoculation (DAI), instead of weekly monitoring, where dead plants are only the ones examined internally, while those that survived were examined at harvest as indicated in the original protocol. Rating scale used are only odd numbers at 1, 3, 5, 7, 9 and 11, instead of the original scale from Carlier with 1, 2, 3, 4, 5 and 6, respectively. The descriptions are as follows: (1) corm completely clean, no vascular discoloration, (3) isolated points of discoloration on vascular tissue (5), discoloration of up to $1 / 3$ of vascular tissue, (7) discoloration of between $1 / 3$ and $2 / 3$ of vascular tissue, (9) discoloration of greater than $2 / 3$ of vascular tissue, (11) total discoloration of vascular tissue.

\subsection{DNA Extraction and Quantification}

Single-spore cultures of each isolate were used for DNA extraction using the CTAB method [29] with some modifications. Isolates were grown in Potato Dextrose Broth (PDB) for 5-7 days without shaking. Mycelia were harvested through the use of sterile filter paper and/or forceps and dried using sterilized paper towel. Mycelia were then freeze-dried and ground to a fine powder in liquid nitrogen using sterilized mortar and pestle. One ml CTAB extraction buffer was added and mixed thoroughly. The resulting solution was then transferred to $1.5 \mathrm{~mL}$ Eppendorf tubes, followed by incubation at $55^{\circ} \mathrm{C}$ for $1 \mathrm{~h}$. DNA purification was done through addition of phenol-chloroform-isoamyl (PCI), centrifuged for $10 \mathrm{~min}$ at 15,000 rpm where supernatant containing DNA was obtained and placed in a fresh Eppendorf tubes. The next step was precipitation with isopropanol at $-20^{\circ} \mathrm{C}$ for $1 \mathrm{~h}$, followed by centrifugation for $15 \mathrm{~min}$ at 13,000 rpm. DNA pellets were washed with 70\% ethanol and resuspended in TE buffer. DNA samples were quantified using Nanodrop spectrophotometer and standardize to $50 \mathrm{ng} \mathrm{\mu L}^{-1}$ and $100 \mathrm{ng} \mathrm{\mu L}^{-1}$ with diethylpyrocarbonate (DEPC) water before storing at $-20^{\circ} \mathrm{C}$ for further molecular analyses.

Foc isolates, tested positive to TR4 under VCG 1213 [30] were provided by the Department of Agriculture in Tagum City as control.

\subsection{PCR-Based Race Identification}

Using race specific primers designed by Dita [27] FocTR4-F)/FocTR4-R for TR4, and Lin [31] for Race 4, DNA was amplified using a thermal cycler (BioRad, Hercules, CA, USA) with the following conditions and some modifications: initial denaturation at $95^{\circ} \mathrm{C}$ for $5 \mathrm{~min}$ and 30 cycles of denaturation at $95{ }^{\circ} \mathrm{C}$ for $1 \mathrm{~min}$, annealing at $60^{\circ} \mathrm{C}$ for $1 \mathrm{~min}$ and extension at $72{ }^{\circ} \mathrm{C}$ for $3 \mathrm{~min}$, followed by an additional extension time for $10 \mathrm{~min}$ at $72{ }^{\circ} \mathrm{C}$. FocTR4-F/FocTR4-R and Foc-1/Foc-2 are expected to generate unique amplicon of 463 base pairs (bp) and 242 bp, respectively. Each amplification reaction mixture volume was $15 \mu \mathrm{L}$ containing $50 \mathrm{ng} \mu \mathrm{L}^{-1} \mathrm{DNA}, 0.2 \mu \mathrm{M}$ of each primer, $0.2 \mathrm{mM}$ deoxynucleoside triphosphates(dNTPs), $2.5 \mathrm{mM} \mathrm{MgCl} 2,0.6 \mathrm{U}$ Taq DNA polymerase, $1 \mathrm{X}$ PCR buffer $\left(-\mathrm{MgCl}_{2}\right)$ and DEPC-treated water.

\subsection{DNA Fingerprinting}

To analyze diversity of Foc, arbitrarily primed-PCR using M13 primer and amplification of repetitive sequences in the Foc genome with ERIC, REP and BOX primers were conducted. All amplification procedures using a thermal cycler (BioRad) were done twice to confirm consistency of the method.

\subsection{Enterobacterial Repetitive Intergenic Consensus (ERIC)-PCR}

PCR amplifications were carried out in a $25 \mu \mathrm{L}$ reaction mixtures using primer pairs ERIC1R (5'-ATG TAA GCT CCT GGG GAT TCA C-3') and ERIC2 (5'-AAG TAA GTG ACT GGG GTG AGC G-3') [22]. The reaction mixture consisted of the following components: 1 X PCR buffer, $2.5 \mathrm{mM} \mathrm{MgCl}_{2}$, $0.2 \mathrm{mM}$ of dNTPs, $0.67 \mu \mathrm{M}$ of each primer, $1.0 \mathrm{U}$ of Taq polymerase, $50 \mathrm{ng}$ of genomic DNA and DEPC-treated water. PCR amplification conditions were as follows: initial denaturation at $95^{\circ} \mathrm{C}$ for $7 \mathrm{~min}, 35$ cycles of denaturation at $95^{\circ} \mathrm{C}$ for $1 \mathrm{~min}$, annealing at $48^{\circ} \mathrm{C}$ for $1 \mathrm{~min}$ and extension at $65^{\circ} \mathrm{C}$ for $8 \mathrm{~min}$. Final extension was conducted at $65^{\circ} \mathrm{C}$ for $15 \mathrm{~min}$ to ensure complete extension. 


\subsection{Repetitive Extragenic Palindromic (REP)—PCR}

Using primer set REP1R (5'-IIIICGIICGICATCIGGC-3') and REP2 (5'-ICGICTTATCIGGCCTAC-3') in $25 \mu \mathrm{L}$ reaction mixture with all other PCR ingredients the same as ERIC-PCR, amplification was carried out using the following conditions: Initial denaturation at $95{ }^{\circ} \mathrm{C}$ for $7 \mathrm{~min}, 35$ cycles of denaturation at $94{ }^{\circ} \mathrm{C}$ for $1 \mathrm{~min}$, annealing at $40{ }^{\circ} \mathrm{C}$ for $1 \mathrm{~min}$ and extension at $65^{\circ} \mathrm{C}$ for $8 \mathrm{~min}$. Final extension was conducted at $65^{\circ} \mathrm{C}$ for $15 \mathrm{~min}$ to ensure complete extension.

\subsection{BOX Elements}

Reaction was carried out using BOX primer (5'-CTA CGC CAA GGC GAC GCT GAC G-3') in a $25 \mu \mathrm{L}$ mixture with the same concentration of PCR ingredients mentioned earlier in ERIC and REPPCR. Amplification was carried out with the following conditions: initial denaturation at $95^{\circ} \mathrm{C}$ for $7 \mathrm{~min}, 35$ cycles of denaturation at $94{ }^{\circ} \mathrm{C}$ for $1 \mathrm{~min}$, annealing at $55^{\circ} \mathrm{C}$ for $1 \mathrm{~min}$ and extension at $65^{\circ} \mathrm{C}$ for $8 \mathrm{~min}$. Fifteen minutes final extension was conducted at $65^{\circ} \mathrm{C}$.

\subsection{RAPD Using M13 Primer}

The repeated sequence from the protein II region of M13 phage MR (5'-GAGGGTGGCGGTTCT-3') one of the two primers, which was previously described for fingerprinting filamentous fungi by [32] was also evaluated. Amplification was performed in a 15- $\mu \mathrm{L}$ reaction composed of $1 \mathrm{X}$ PCR Buffer $\left(-\mathrm{MgCl}_{2}\right), 1.5 \mathrm{mM} \mathrm{MgCl} 2,0.2 \mathrm{mM}$ dNTP, $1.0 \mu \mathrm{M}$ of M13 primer and $0.8 \mathrm{U}$ of Taq polymerase and DEPC-treated water with the following conditions: 1 cycle of $94{ }^{\circ} \mathrm{C}$ for $4 \mathrm{~min}, 50{ }^{\circ} \mathrm{C}$ for $1 \mathrm{~min}$ and $72{ }^{\circ} \mathrm{C}$ for $2 \mathrm{~min}$, followed by 40 cycles of denaturation at $94{ }^{\circ} \mathrm{C}$ for $1 \mathrm{~min}$ annealing at $50{ }^{\circ} \mathrm{C}$ for $1 \mathrm{~min}$ and extension at $72{ }^{\circ} \mathrm{C}$ for $2 \mathrm{~min}$, final extension is carried out at $72{ }^{\circ} \mathrm{C}$ for $10 \mathrm{~min}$.

\subsection{Electrophoresis of PCR Products and Gel Documentation}

PCR products were run using an electrophoretic tank (BioRad) containing 0.5X TAE running buffer. For race identification, running conditions include $1.2 \%$ agarose at $110 \mathrm{~V}$ for approximately $45 \mathrm{~min}$. For all fingerprinting techniques, $1.5 \%$ agarose gel was used in $50 \mathrm{~V}$ voltage for a total of $3 \mathrm{~h}$ running time. Agarose gels were then stained using Gel Red for $25 \mathrm{~min}$, and viewed under Gel Doc (BioRad) equipped with Image Lab Software.

\subsection{Phenetic Analyses}

The genetic relatedness of each isolate was analyzed using the generated banding patterns. A separate data matrix was constructed for each primer by scoring each isolate for the presence or absence of each band. Bands were initially assigned a number in relation to their migration distance within the gel, where highest molecular weight as assigned number one and so on until the band with the lowest molecular weight. It was assumed that the bands with the same molecular weight in different individuals were identical in sequence. To obtain a binary banding data, only strong and reproducible bands were scored, where the presence or absence of each band was determined and designated 1 if present, and 0 if absent. Similarity matrices from binary banding data of each of the three primer combinations were derived with the Similarity for Qualitative Data Program (SIMQUAL) in the Numerical Taxonomy and Multivariate analysis System for personal computer (NTSYS-pc) version 2.1 [33]. Estimates for similarity were based on Jaccards coefficient, where matrices were analyzed and clustered using Unweighted Pair Group Method with Arithmetic averages (UPGMA) as previously described by Bentley et al. [34]. Dendrograms were obtained using the tree option of NTSYS-pc. In order to generate data including all primers used, band matrices from three primer sets were pooled and subjected through the same analyses as mentioned above. Bootstrap analysis of binary data to determine confidence limits was conducted using WINBOOT [35]. 


\section{Results and Discussion}

\subsection{Survey and Collection}

A total of 164 isolates were collected from 26 areas covering 12 provinces in five regions of Luzon, Philippines (Figure 1 and Table 1). Random sampling was done in areas where bananas exhibited external symptoms characterized by yellowing of the leaf margins of older leaves and/or collapse of leaves at the petiole. Discolorations in the pseudostems were also visible during destructive sampling.

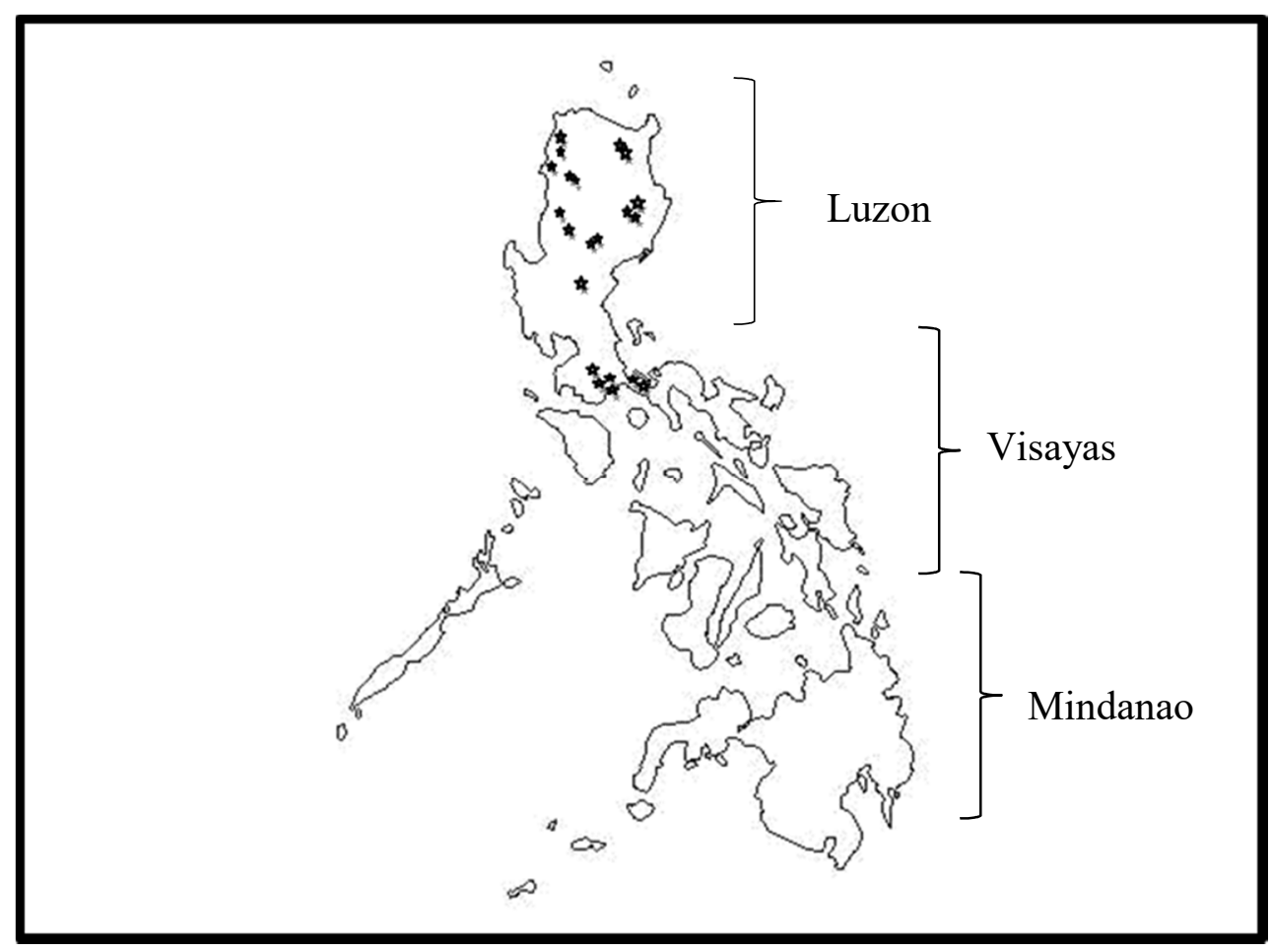

Figure 1. Places of collection in Luzon Philippines.

Bananas surveyed in Luzon Philippines, were found mainly as backyard plants used for personal or local consumption (if sold in the local market). Lakatan, Latundan and Saba are the most common varieties grown in the different regions. While Lakatan and Latundan were found in larger farms, which were remote and were not easily accessible, Saba is commonly found alongside the roads or beside houses. Some samples were sent directly to the laboratory, which were collected by the Municipal Agricultural Office in Tiaong, Quezon. Samples collected were immediately isolated in the laboratory. After a 1 to 2 week incubation colonies produced in PDA plate were further purified into monoconidial cultures. 
Table 1. List of Foc isolates collected from different areas in Luzon, Philippines.

\begin{tabular}{|c|c|c|c|}
\hline No. & Place of Collection & Variety & Isolate Code \\
\hline \multicolumn{4}{|c|}{ Region I } \\
\hline 1 & Lubnac, Tagudin, Ilocos Sur & Latundan & IB1, 1B2, 1B3 \\
\hline & & & $\begin{array}{c}\text { 12A1, 12A2, 12A3, 12B, 13B1, } \\
\text { 13B2a, 13B2b, 14A, 14A1a, } \\
\text { 14A1b, 14A1c, 14A2, 14A3, 14B1, }\end{array}$ \\
\hline 2 & Bario-an, Tagudin, Iloc Sur & Latundan & $14 \mathrm{~B} 2,15 \mathrm{~A}$ \\
\hline & & Tomok & $\begin{array}{c}\text { 16B1, 16B2, 16B3, 18A1, 18A2, } \\
\text { 18B1, 18B2, 18B3a, 18B3b }\end{array}$ \\
\hline 3 & Dardarat, Pinili, Ilocos Sur & Unknown & 119B1, 119B2 \\
\hline 4 & Ipet, Sudipen, La Union & Tomok & 19A, 19B1a, 19B1b, 19B2, 19B3 \\
\hline & & Lakatan & $\begin{array}{c}24 \mathrm{~A}, 24 \mathrm{~A} 1,24 \mathrm{~A} 2 \mathrm{a}, 24 \mathrm{~A} 2 \mathrm{~b}, 24 \mathrm{~A} 2 \mathrm{c} \\
24 \mathrm{~A} 3,24 \mathrm{~B} 1,24 \mathrm{~B} 2\end{array}$ \\
\hline 5 & Camanggaan, Laoag City & Unknown & $122,123 \mathrm{~A}, 123 \mathrm{~B}, 124 \mathrm{~A}$ \\
\hline \multicolumn{4}{|c|}{ Region II } \\
\hline 6 & Fabrica, Lallo, Cagayan & Lakatan & $\begin{array}{c}\text { 57A, 57B2, 58A2.1, 58A2.2, 58A3, } \\
\text { 60A1, 60A2, 62B1, 62B2 } \\
\text { 64A1.1, 64A1.2, 64A2.1, 64A2.2, } \\
67 \mathrm{~A}, 67 \mathrm{~B} 1,69 \mathrm{~B}, 73 \mathrm{C}\end{array}$ \\
\hline 7 & Cagoran, lallo Cagayan & Lakatan & $55 \mathrm{~B}$ \\
\hline 8 & San Fabian, Echague, Isabela & Latundan & $38 \mathrm{D}, 39 \mathrm{~A}, 39 \mathrm{~B}, 39 \mathrm{~B} 1,39 \mathrm{~B} 2,39 \mathrm{~B} 3$ \\
\hline 9 & Poblacion, Cauayan, Isabela & Saba & $43 \mathrm{~A}, 43 \mathrm{~B} 1,43 \mathrm{~B} 2,43 \mathrm{~B} 3$ \\
\hline 10 & Mabini, Alicia, Isabela & Lakatan & $48 \mathrm{~A} 1,48 \mathrm{~A} 2,49 \mathrm{~B}$ \\
\hline 11 & Alinam, Cauayan, Isabela & Lakatan & $50 \mathrm{~A}, 50 \mathrm{~A} 1,50 \mathrm{~A} 2,51 \mathrm{~A}, 51 \mathrm{~B} 1,52 \mathrm{~A}$ \\
\hline 12 & Kinakaw, Bagabag, NuevaVizcaya & Saba & $29 \mathrm{~A} 1,31 \mathrm{~A}, 31 \mathrm{~B}, 32 \mathrm{~A}, 32 \mathrm{~B}$ \\
\hline 13 & $\begin{array}{c}\text { Magsaysay, Bayombong, Nueva } \\
\text { Vizcaya }\end{array}$ & Lakatan & 36A1, 36A2, 36B1, 36B2 \\
\hline \multicolumn{4}{|c|}{ Region III } \\
\hline 14 & CLSU, Munoz, Nueva Ecija & Unknown & $84 \mathrm{~B}, 85 \mathrm{~A}, 85 \mathrm{~B}$ \\
\hline \multicolumn{4}{|c|}{ Region IV } \\
\hline 15 & Tayabas, Quezon & Saba & 93A, 93B, 83C, 93D1, 93D2 \\
\hline 16 & Talisay, Tiaong, Quezon & Latundan & $\begin{array}{c}\text { 128, 101A2, 101B1.1, 101B1.2, } \\
\text { 101B1.3,101B2.1, 101B2.2, 101B2.3, } \\
\text { 101C1.1, 101C1.2, 101C1.3, 101D, } \\
\text { 101D2.1, 101D2.2, 102B1, 102B2, } \\
\text { 102B3, 102C1, 102C2, 102D1, }\end{array}$ \\
\hline 17 & Tiaong, Quezon & Lakatan & 102D2,131A1, 131A2, 131B1, 131B2 \\
\hline 18 & Bukal Sur, Quezon & Latundan & $132 \mathrm{~A}, 132 \mathrm{~B}, 143 \mathrm{~A} 1,142 \mathrm{~A} 2,143 \mathrm{~B}, 144 \mathrm{~A} 1$, \\
\hline 19 & Masalukot II, Candelaria, Quezon & Lakatan & $144 \mathrm{~A} 2,144 \mathrm{~B}$ \\
\hline 20 & San Felix, Sto. Tomas, Batangas & Unknown & 98B1, 98B2, 99D, 100B1, 100B2 \\
\hline 21 & Tranca, Bay, Laguna & Latundan & $104 \mathrm{~B} 1,106 \mathrm{~B} 1$ \\
\hline & & & 114A1, 114A2.1, 114A2.2, 114B1, \\
\hline 22 & Lawaguin, Nagcarlan, Laguna & Unknown & $114 \mathrm{~B} 2$ \\
\hline 23 & Sabang, Nagcarlan, Laguna & Saba & 116A1, 116B1, 116B2.1, 116B2.2 \\
\hline \multicolumn{4}{|c|}{ CAR } \\
\hline 24 & Luzong, Luba, Abra & Unknown & $\begin{array}{c}\text { 74B, 75B, 76A, 76B, 77A, 77A2 } \\
\text { 79A, 80A1, 80A2, 81B, 82A } 1\end{array}$ \\
\hline 25 & Tobanggao, Poblacion, Abra & Unknown & $82 \mathrm{~A} 2$ \\
\hline 26 & Tublay, Benguet & Saba & $94 \mathrm{~A}, 94 \mathrm{~B}$ \\
\hline
\end{tabular}

\subsection{Morphological Characterization}

Isolates in PDA varied widely in morphology after 7 days incubation. Color ranged from pale violet, pale orange to dark magenta and some without pigment. Appearance of mycelia varied from 
flat to aerial, floccose to cottony and circular to irregular form. Some were fast growing, reaching $5 \mathrm{~cm}$ in diameter, while others were slow growing reaching only $2 \mathrm{~cm}$ after 7 days incubation. Some isolates transformed into pionnotal form characterized by a flat 'wet' mycelia colony when frequent subculture is done in PDA. The presence of transposable elements that promote changes in the gene expression might have been the reason behind these phenotypic variation in Foc isolates [36,37].

Microconidia produced by majority of the isolates were oval and kidney shaped, usually single-celled, some with single septation borne from short monophialides and seen as false heads with aerial mycelium presentation. All isolates produced plenty of microconidia, with the exception of 43B2 and 43B3. Macroconidia were usually 3-septated, thin, straight to sickle-shaped with distinct foot cell. Characteristics of chlamydospores which were observed in some isolates greatly varied, with the presence of both smooth and coarse protective wall, which are singly, in pairs or even clusters found in terminal or intercalary. Morphological features are in agreement with the description of Leslie and Summerell [26].

Pathogenicity tests were conducted in two batches due to limited 'clean' planting materials from the tissue culture laboratories, of National Plant Genetic Resources Laboratory, Institute of Plant Breeding, University of the Philippines Los Baños. Isolates were prepared simultaneously with the potting out of tissue-cultured plantlets in time for inoculation. All isolates fully colonized corn meal-sand media 10 days after incubation.

A total of 45 isolates with four replicates were tested representing different places of collection in Luzon (Table 2). There were no pathogenicity tests conducted using Mindanao isolates due to quarantine issues. Variation between the first and second set up include age of test plants which were 6 weeks and 4 weeks old, respectively. Flonicamid, an insecticide for the control of all aphid species was sprayed once at 7 DAI. Based on weekly visual observation, first symptom appearance started at 21 DAI on isolate 24A2a isolated from Lakatan in Mabini, Alicia Isabela, characterized by yellowing of margins in the older leaves. Additional plants manifested wilting symptoms at 28 DAI. Some inoculated plants did not manifest wilting symptoms, but vascular discoloration was evident during destructive sampling at $45 \mathrm{DAI}$, thus were generally considered not aggressive. Based on the mean of four replicates, majority of the isolates did not manifest leaf symptoms. The highest rating, based on mean of four replicates was 3, characterized by slight streaking or yellowing of lower leaves (Figure 2A). Vascular discoloration rating of isolates 102D1, 24A2a and 116B2.1 were the highest with rating of 5 and 7 characterized by isolated points of discoloration up to 2/3 of the vascular tissue. Mild discolorations up to $1 / 3$ of the vascular tissue were observed in majority of the isolates (Figure 2B). Interestingly, most isolates with high vascular rating also had leaf symptoms. Isolates with highest rating in both parameters for disease severity were generally aggressive based on the days of symptoms appearance after inoculation. Three isolates, 64A2, 74B and 119B1 were considered non- pathogenic, with $0 \%$ infection. Considering morphological characterization performed earlier, determination of pathogenic and non-pathogenic elements that might have induced mutation strains of F. oxysporum is found to be indistinguishable, consistent with the study of Lievens et al. [38] making diagnosis via morphological characters impossible. 
Table 2. Pathogenicity of representative Foc isolates on the Latundan variety of banana expressed in days after first symptoms appearance, leaf symptom index and vascular discoloration rating.

\begin{tabular}{|c|c|c|c|c|c|c|}
\hline No & $\begin{array}{l}\text { Isolate } \\
\text { Code }\end{array}$ & $\begin{array}{l}\text { Place of } \\
\text { Collection }\end{array}$ & $\begin{array}{l}\text { Variety Where } \\
\text { Isolated }\end{array}$ & $\begin{array}{c}\text { Days After First } \\
\text { Symptom } \\
\text { Appearance }\end{array}$ & $\begin{array}{c}\text { Leaf } \\
\text { Symptom } \\
\text { Index }^{1}\end{array}$ & $\begin{array}{c}\text { Vascular } \\
\text { Discoloration } \\
\text { Rating }^{2}\end{array}$ \\
\hline 1 & 1B1 & $\begin{array}{l}\text { Lubnac, Tagudin, } \\
\text { Ilocos Sur }\end{array}$ & Latundan & 45 & 1.00 & 3.00 \\
\hline 2 & $12 \mathrm{~A} 2$ & $\begin{array}{l}\text { Bario-an, Tagudin, } \\
\text { Ilocos Sur }\end{array}$ & Latundan & 45 & 1.00 & 1.50 \\
\hline 3 & $13 \mathrm{~B} 2 \mathrm{~b}$ & $\begin{array}{l}\text { Bario-an, Tagudin, } \\
\text { Ilocos Sur }\end{array}$ & Latundan & 45 & 1.00 & 2.50 \\
\hline 4 & 14A1B & $\begin{array}{l}\text { Bario-an, Tagudin, } \\
\text { Ilocos Sur }\end{array}$ & Latundan & 35 & 2.00 & 3.50 \\
\hline 5 & 16B1 & $\begin{array}{l}\text { Bario-an, Tagudin, } \\
\text { Ilocos Sur }\end{array}$ & Tomok & 45 & 1.00 & 2.50 \\
\hline 6 & 18A1 & $\begin{array}{l}\text { Bario-an, Tagudin, } \\
\text { Ilocos Sur }\end{array}$ & Tomok & 45 & 1.00 & 3.00 \\
\hline 7 & $19 \mathrm{~A}$ & $\begin{array}{l}\text { Ipet, Sudipen, } \\
\text { La Union }\end{array}$ & Tomok & 45 & 1.00 & 3.00 \\
\hline 8 & $24 \mathrm{~A} 2 \mathrm{a}$ & $\begin{array}{l}\text { Ipet, Sudipen, } \\
\text { La Union }\end{array}$ & Lakatan & 28 & 3.00 & 4.50 \\
\hline 9 & $32 \mathrm{~A}$ & $\begin{array}{l}\text { Kinakaw, Bagabag, } \\
\text { Nueva Vizcaya }\end{array}$ & Saba & 28 & 3.00 & 2.50 \\
\hline 10 & $32 \mathrm{~B}$ & $\begin{array}{c}\text { Kinakaw, Bagabag, } \\
\text { Nueva Vizcaya }\end{array}$ & Saba & 28 & 2.50 & 1.50 \\
\hline 11 & 36B1 & $\begin{array}{c}\text { Magsaysay, } \\
\text { Bayombong, } \\
\text { Nueva Vizcaya }\end{array}$ & Lakatan & 28 & 1.50 & 2.50 \\
\hline 12 & $39 \mathrm{~A}$ & $\begin{array}{c}\text { San Fabian, } \\
\text { Echague, Isabela }\end{array}$ & Latundan & 28 & 3.00 & 3.50 \\
\hline 13 & 39B & $\begin{array}{c}\text { San Fabian, } \\
\text { Echague, Isabela }\end{array}$ & Latundan & 35 & 2.50 & 3.50 \\
\hline 14 & $43 \mathrm{~A}$ & $\begin{array}{c}\text { Poblacion, } \\
\text { Cauayan, Isabela }\end{array}$ & Saba & 28 & 1.50 & 2.00 \\
\hline 15 & $43 \mathrm{~B} 2$ & $\begin{array}{c}\text { Poblacion, } \\
\text { Cauayan, Isabela }\end{array}$ & Saba & 35 & 2.00 & 2.50 \\
\hline 16 & 48A1 & $\begin{array}{l}\text { Mabini, Alicia, } \\
\text { Isabela }\end{array}$ & Lakatan & 21 & 2.50 & 2.50 \\
\hline 17 & $50 \mathrm{~A}$ & $\begin{array}{c}\text { Alinam, Cauayan, } \\
\text { Isabela }\end{array}$ & Lakatan & 35 & 1.50 & 2.50 \\
\hline 18 & $55 B$ & $\begin{array}{c}\text { Cagoran, Lallo, } \\
\text { Cagayan }\end{array}$ & Lakatan & 45 & 1.00 & 1.50 \\
\hline 19 & $57 \mathrm{~A}$ & $\begin{array}{l}\text { Fabrica, Lallo, } \\
\text { Cagayan }\end{array}$ & Lakatan & 45 & 1.00 & 1.50 \\
\hline 20 & 57B2 & $\begin{array}{c}\text { Fabrica, Lallo, } \\
\text { Cagayan }\end{array}$ & Lakatan & 45 & 1.00 & 2.50 \\
\hline 21 & 58A2.1 & $\begin{array}{c}\text { Fabrica, Lallo, } \\
\text { Cagayan }\end{array}$ & Lakatan & 42 & 2.00 & 3.00 \\
\hline 22 & $60 \mathrm{~A} 2$ & $\begin{array}{c}\text { Fabrica, Lallo, } \\
\text { Cagayan }\end{array}$ & Lakatan & 28 & 3.00 & 2.50 \\
\hline
\end{tabular}


Table 2. Cont.

\begin{tabular}{|c|c|c|c|c|c|c|}
\hline No & $\begin{array}{l}\text { Isolate } \\
\text { Code }\end{array}$ & $\begin{array}{l}\text { Place of } \\
\text { Collection }\end{array}$ & $\begin{array}{l}\text { Variety Where } \\
\text { Isolated }\end{array}$ & $\begin{array}{c}\text { Days After First } \\
\text { Symptom } \\
\text { Appearance }\end{array}$ & $\begin{array}{c}\text { Leaf } \\
\text { Symptom } \\
\text { Index }{ }^{1}\end{array}$ & $\begin{array}{c}\text { Vascular } \\
\text { Discoloration } \\
\text { Rating }^{2}\end{array}$ \\
\hline 23 & $64 \mathrm{~A} 2.1$ & $\begin{array}{l}\text { Fabrica, Lallo, } \\
\text { Cagayan }\end{array}$ & Latundan & 0 & 1.00 & 1.00 \\
\hline 24 & $67 \mathrm{~A}$ & $\begin{array}{l}\text { Fabrica, Lallo, } \\
\text { Cagayan }\end{array}$ & Latundan & 35 & 1.50 & 2.50 \\
\hline 25 & 67B1 & $\begin{array}{l}\text { Fabrica, Lallo, } \\
\text { Cagayan }\end{array}$ & Latundan & 42 & 1.50 & 2.50 \\
\hline 26 & $73 C$ & $\begin{array}{l}\text { Fabrica, Lallo, } \\
\text { Cagayan }\end{array}$ & Latundan & 45 & 1.00 & 2.00 \\
\hline 27 & $74 \mathrm{~B}$ & $\begin{array}{l}\text { Luzong, Luba, } \\
\text { Abra }\end{array}$ & Unknown & 0 & 1.50 & 2.50 \\
\hline 28 & 80A1 & $\begin{array}{c}\text { Tobanggao, } \\
\text { Poblacion, Abra }\end{array}$ & Unknown & 35 & 1.50 & 2.50 \\
\hline 29 & $81 \mathrm{~B}$ & $\begin{array}{c}\text { Tobanggao, } \\
\text { Poblacion, Abra }\end{array}$ & Unknown & 45 & 1.00 & 2.00 \\
\hline 30 & $85 \mathrm{~A}$ & $\begin{array}{l}\text { CLSU, Munoz, } \\
\text { Nueva Ecija }\end{array}$ & Unknown & 42 & 2.50 & 3.00 \\
\hline 31 & $93 \mathrm{~A}$ & Tayabas, Quezon & Saba & 35 & 3.00 & 2.50 \\
\hline 32 & $94 \mathrm{~A}$ & Tublay, Benguet & Saba & 35 & 3.00 & 2.00 \\
\hline 33 & 99D & $\begin{array}{l}\text { San Felix, Sto. } \\
\text { Tomas, Batangas }\end{array}$ & Unknown & 35 & 1.50 & 3.50 \\
\hline 34 & 101A2 & Tiaong, Quezon & Lakatan & 28 & 2.50 & 1.50 \\
\hline 35 & 101B1.2 & Tiaong, Quezon & Lakatan & 28 & 1.50 & 3.00 \\
\hline 36 & $102 \mathrm{C} 2$ & Tiaong, Quezon & Lakatan & 35 & 2.00 & 2.00 \\
\hline 37 & 102D1 & $\begin{array}{l}\text { Talisay, Tiaong, } \\
\text { Quezon }\end{array}$ & Lakatan & 28 & 3.00 & 5.00 \\
\hline 38 & 104B1 & $\begin{array}{l}\text { Tranca, Bay, } \\
\text { Laguna }\end{array}$ & Latundan & 45 & 1.00 & 4.00 \\
\hline 39 & 114B1 & $\begin{array}{l}\text { Nagcarlan, } \\
\text { Laguna }\end{array}$ & Unknown & 35 & 1.50 & 1.50 \\
\hline 40 & 116A1 & $\begin{array}{l}\text { Nagcarlan, } \\
\text { Laguna }\end{array}$ & Saba & 35 & 2.00 & 3.00 \\
\hline 41 & 116B2.1 & $\begin{array}{l}\text { Nagcarlan, } \\
\text { Laguna }\end{array}$ & Saba & 35 & 3.00 & 4.50 \\
\hline 42 & 119B1 & Ilocos Sur & Unknown & 0 & 1.00 & 1.00 \\
\hline 43 & 131A1 & Bukal Sur, Quezon & Latundan & 42 & 1.50 & 2.50 \\
\hline 44 & $143 \mathrm{~A} 2$ & $\begin{array}{c}\text { Masalukot II } \\
\text { Candelaria, } \\
\text { Quezon }\end{array}$ & Lakatan & 42 & 2.00 & 3.00 \\
\hline 45 & 144A1 & $\begin{array}{l}\text { Masalukot II } \\
\text { Candelaria, } \\
\text { Quezon }\end{array}$ & Lakatan & 45 & 1.00 & 1.50 \\
\hline
\end{tabular}

\footnotetext{
${ }^{1}$ Leaf Symptoms Index: 1-no streaking/yellowing of older leaves, plants appear healthy; 3-Slight streaking or yellowing of older leaves; 5-streaking or yellowing on most of lower leaves; 7-extensive streaking or yellowing on all of the leaves; 9 - dead/wilted plants. Ratings are mean of four replicates. ${ }^{2}$ Vascular Discoloration Rating: 1 -Corm completely clean, no vascular discoloration; 3 -Isolated points of discoloration on vascular tissue; 5-discoloration of up to $1 / 3$ of vascular tissue; 7 -discoloration of between $1 / 3$ and $2 / 3$ of vascular tissue; 9 -discoloration of greater than $2 / 3$ of vascular tissue; 11 -total discoloration of the vascular tissue. Ratings are mean of four replicates.
} 


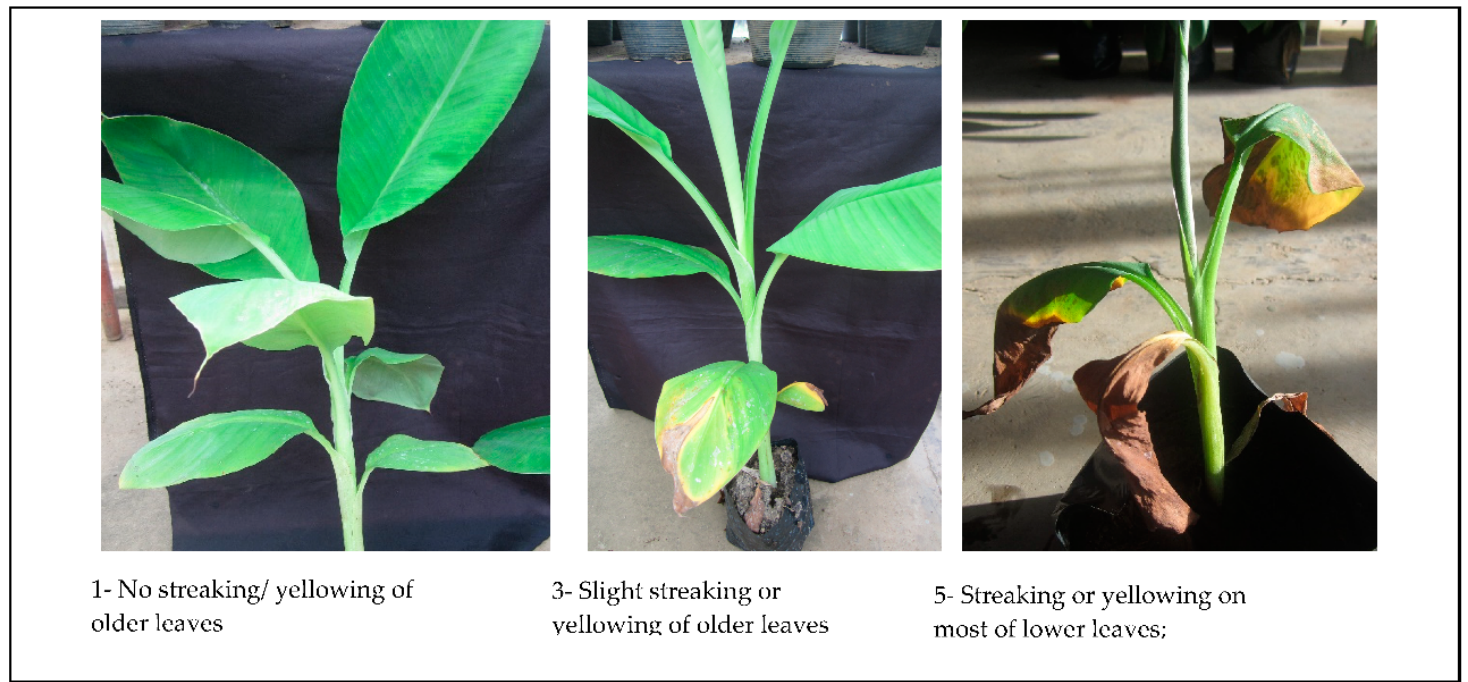

(A)

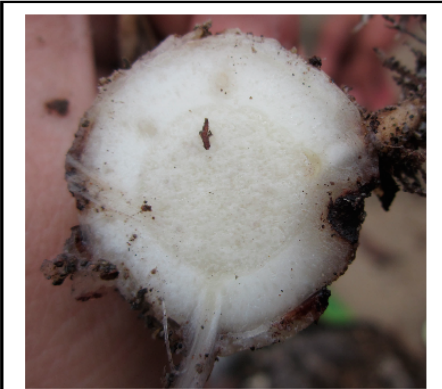

1-Corm completely clean, no vascular discoloration

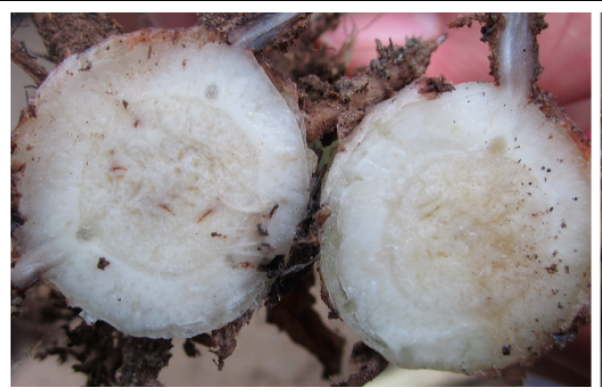

3-Isolated points of discoloration in vascular tissue

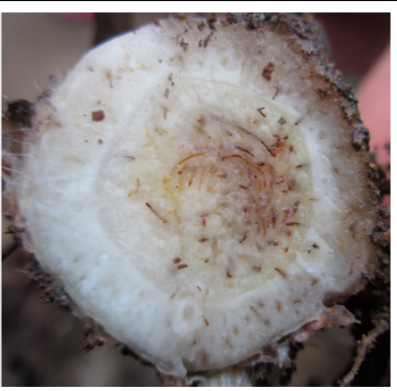

5-Discoloration of up to $1 / 3$ of vascular tissue
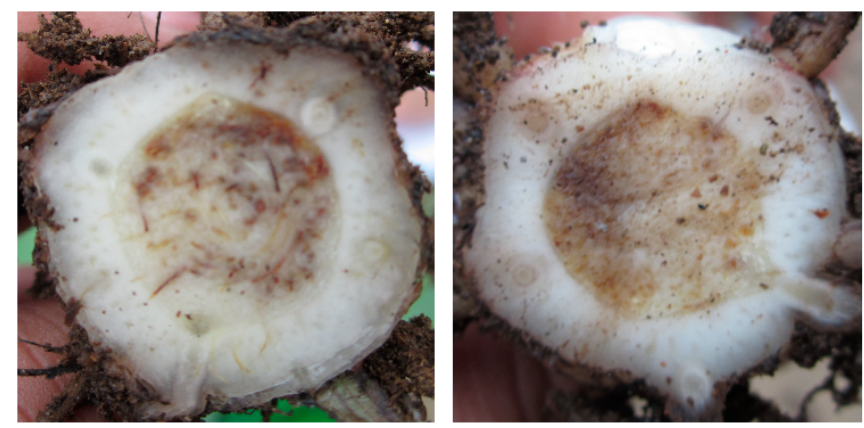

7-Discoloration of greater than 2/3 of vascular tissue

(B)

Figure 2. (A). Sample representatives of plants with leaf symptoms. Majority of the isolates tested had very mild leaf symptoms in test plants, none of which exhibited symptoms with rating scale of 7 and 9 . (B). Sample representatives of vascular discoloration with different scale, except rating 9 which wasn't observed in all isolates tested.

There were no trends as regards to the geographical distribution and host variety where isolates were obtained. Results indicate majority of the isolates being pathogenic; however, the presence of non-pathogenic F. oxysporum in the population is possible, which according to Fourie et al. [18] are cosmopolitan and can be found in soils, water and plant residues. Non-pathogenic F. oxysporum's 
inability to cause disease is attributed to their lack of means to penetrate the vascular tissue or host plants are able to counteract infections [39]. Importance of non-pathogenic strains should also be considered, since it may serve as source of new pathogenic strains [40] due to close genetic relationship between non-pathogenic and pathogenic isolates [41].

Based on the data, it can be concluded that the inoculation procedure used in this study was efficient enough, since most isolates were able to induce infection in Latundan variety leaving the control healthy and symptomless. It can be further deduced that the tested Foc population was not aggressive when compared to other pathogenicity trials conducted, where symptoms usually appear at 7 DAI [27]. However, it should be taken into consideration that there has been no universally acceptable greenhouse inoculation technique for Foc, which is an important bottleneck for characterization, considering that race identification still heavily relies on pathogenicity trials [27,42-44]. Following Koch's postulates, Foc isolates were successfully re-isolated in PDA from rhizomes manifesting discoloration symptoms. Examination under the microscope was done to ensure identity of Fusarium isolates obtained.

\subsection{DNA Extraction of Foc}

The CTAB method previously described by other researchers to extract DNA from fungi and related organisms was used successfully on Foc isolates [29,45]. The amount of DNA harvested from 5-day old mycelial cultures in PDB ranged from 20-3000 $\mathrm{ng} / \mu \mathrm{L}$. The use of liquid nitrogen significantly increased the amount of DNA harvested, as compared to extraction using CTAB buffer alone.

\subsection{Race Identification Using Race-Specific Primers}

Given the economic importance of TR4, which is currently threatening the global banana industry, accurate identification will aid in quarantine measures, where effective control has not been established. Race classification of Foc, which is solely based on the capacity to infect differential set of cultivars through pathogenicity tests, are often influenced by different factors such as temperature, age of host, amount of inocula and method of inoculation [46], where results vary from around the world [46,47]. Genetically the same species can be classified into different races based on their capacity to infect differential set of cultivars in different locations, where environmental conditions play a vital role [18]. For instance, field data for TR4 or ST4 should be carefully interpreted, where TR4 is more aggressive than ST4 [15,48], the latter can also cause severe damage in Cavendish cultivars, particularly under abiotic stress such as low temperatures and water logging $[15,49,50]$.

Due to the flaws of pathogenicity testing to determine races, PCR-diagnostic procedure, particularly for Race 4 has been demonstrated several times $[18,27,31,51,52]$. Specific primer sets were used in this study as a PCR diagnostic tool to detect presence of TR4 and Race 4 in general. FocTr4-F/FocTr4-R primer set was derived from two single nucleotide polymorphism of the intergenic spacer region (IGS) of the nuclear ribosomal operon of Foc specifically designed in TR4 [27]. In South-Central Mindanao in the Philippines, Solpot et al., [17] identified Foc TR4 isolates collected from North Cotabato, South Cotabato, Saranggani, Davao del Sur and General Santos City isolated from Lakatan, Cavendish and Latundan varieties using primers developed by Lin et al. [31].

Isolates from Mindanao produced the expected $463 \mathrm{bp}$ and $243 \mathrm{bp}$ amplicon during gel electrophoresis using primers FocTr4-F/FocTr4-R and Foc-1/Foc-2, respectively. Using primers FocTr4-F/FocTr4-R, results confirmed absence of TR4. Eleven isolates from Luzon gave positive results and produced the expected $243 \mathrm{bp}$, along with the positive check from Mindanao with primers Foc-1/Foc-2. There were particularly no patterns with regard to the place of collection from Regions 1, II, IV and CAR as well as different varieties including Latundan, Lakatan and Saba from where representative isolates obtained (Table 3 ). 
Table 3. PCR-based Race 4 and TR4 identification of Luzon Foc isolates using primers Foc-1/Foc-2 and FocTR4-F/FocTR4-R.

\begin{tabular}{|c|c|c|c|c|c|}
\hline \multicolumn{2}{|c|}{ Isolate } & \multicolumn{2}{|l|}{ Description } & \multicolumn{2}{|c|}{ PCR-Detection ${ }^{1}$} \\
\hline No. & Code & Place of Collection & Variety & FocTR4 & Foc1/2 Race 4 \\
\hline 1 & 1B3 & Lubnac, Tagudin, Ilocos Sur & Latundan & - & - \\
\hline 2 & $12 \mathrm{~B}$ & Bario-an, Tagudin, Ilocos Sur & Latundan & - & - \\
\hline 3 & $14 \mathrm{~A} 1 \mathrm{~b}$ & Bario-an, Tagudin, Ilocos Sur & Latundan & - & - \\
\hline 4 & $16 \mathrm{~B} 1$ & Lubnac, Tagudin, Ilocos Sur & Tomok & - & - \\
\hline 5 & $18 \mathrm{~B} 3 \mathrm{a}$ & Lubnac, Tagudin, Ilocos Sur & Tomok & - & - \\
\hline 6 & 19B2 & Ipet, Sudipen, La Union & Tomok & - & - \\
\hline 7 & 24B1 & Ipet, Sudipen, La Union & Lakatan & - & - \\
\hline 8 & $24 \mathrm{~A} 2 \mathrm{a}$ & Ipet, Sudipen, La Union & Lakatan & - & + \\
\hline 9 & $31 \mathrm{~A}$ & Kinakaw, Bagabag, Nueva Vizcaya & Saba & - & + \\
\hline 10 & $32 \mathrm{~A}$ & Kinakaw, Bagabag, Nueva Vizcaya & Saba & - & + \\
\hline 11 & $36 \mathrm{~A}$ & Magsaysak, Bayombong, Nueva Vizcaya & Lakatan & - & - \\
\hline 12 & $39 \mathrm{~A}$ & San Fabian, Echague, Isabela & Latundan & - & - \\
\hline 13 & 39B3 & San Fabian, Echague, Isabela & Latundan & - & - \\
\hline 14 & $43 \mathrm{~A}$ & Poblacion, Cauayan, Isabela & Saba & - & - \\
\hline 15 & 43B2 & Poblacion, Cauayan, Isabela & Saba & - & + \\
\hline 16 & 48A1 & Mabini, Alicia, Isabela & Lakatan & - & + \\
\hline 17 & $50 \mathrm{~A}$ & Alinam, Cauayan, Isabela & Lakatan & - & - \\
\hline 18 & 51B1 & Alinam, Cauayan, Isabela & Lakatan & - & - \\
\hline 19 & $55 \mathrm{~B}$ & Cagoran, Lallo, Cagayan & Lakatan & - & - \\
\hline 20 & 57B1 & Fabrica, Lallo, Cagayan & Lakatan & - & - \\
\hline 21 & $58 \mathrm{~A} 3$ & Fabrica, Lallo, Cagayan & Lakatan & - & - \\
\hline 22 & $64 \mathrm{~A} 2.2$ & Fabrica, Lallo, Cagayan & Latundan & - & - \\
\hline 23 & $73 C$ & Fabrica, Lallo, Cagayan & Latundan & - & - \\
\hline 24 & $74 \mathrm{~B}$ & Luzong, Luba, Abra & Unknown & - & - \\
\hline 25 & $77 \mathrm{~A} 2$ & Luzong, Luba, Abra & Unknown & - & - \\
\hline 26 & $80 \mathrm{~A} 2$ & Tobanggao, Poblacion, Abra & Unknown & - & - \\
\hline 27 & 82A1 & Tobanggao, Poblacion, Abra & Unknown & - & - \\
\hline 28 & $84 \mathrm{~B}$ & CLSU, Munoz, Nueva Ecija & Unknown & - & - \\
\hline 29 & $93 \mathrm{~A}$ & Tayabas, Quezon & Saba & - & + \\
\hline 30 & $93 \mathrm{~B}$ & Tayabas, Quezon & Saba & - & - \\
\hline 31 & $93 \mathrm{C}$ & Tayabas, Quezon & Saba & - & - \\
\hline 32 & $94 \mathrm{~A}$ & Tublay, Benguet & Saba & - & + \\
\hline 33 & 98B1 & San Felix, Sto. Tomas, Batangas & Unknown & - & - \\
\hline 34 & 99D & San Felix, Sto. Tomas, Batangas & Unknown & - & - \\
\hline 35 & $101 \mathrm{~A} 2$ & Tiaong, Quezon & Latundan & - & + \\
\hline 36 & 101B2 & Tiaong, Quezon & Latundan & - & + \\
\hline 37 & 102D1 & Tiaong, Quezon & Latundan & - & + \\
\hline 38 & $101 C 1.1$ & Tiaong, Quezon & Latundan & - & - \\
\hline 39 & 104B1 & Tranca, Bay, Laguna & Latundan & - & + \\
\hline 40 & 106B1 & Tranca, Bay, Laguna & Latundan & - & - \\
\hline 41 & 114A1 & Lawaguin, Nagcarlan, Laguna & Unknown & - & - \\
\hline 42 & 114A2.1 & Lawaguin, Nagcarlan, Laguna & Unknown & - & - \\
\hline 43 & 116B1 & Sabang, Nagcarlan, Laguna & Unknown & - & - \\
\hline 44 & 116B2.1 & Sabang, Nagcarlan, Laguna & Unknown & - & - \\
\hline 45 & 119B1 & Dardarat, Pinili, Ilocos Sur & Unknown & - & - \\
\hline 46 & 119B2 & Dardarat, Pinili, Ilocos Sur & Unknown & - & - \\
\hline 47 & $123 \mathrm{~A}$ & Camanggaan, Laoag City & Unknown & - & - \\
\hline 48 & $123 B$ & Camanggaan, Laoag City & Unknown & - & - \\
\hline 49 & 128 & Talisay, Tiaong, Quezon & Latundan & - & - \\
\hline 50 & 131B1 & Bukal Sur, Quezon & Latundan & - & - \\
\hline 51 & $132 \mathrm{~B}$ & Bukal Sur, Quezon & Latundan & - & - \\
\hline 52 & $143 \mathrm{~A} 1$ & Masalukot II, Candelaria, Quezon & Lakatan & - & - \\
\hline 53 & 144A1 & Msalukot II, Candelaria, Quezon & Lakatan & - & - \\
\hline 54 & $1213=1$ & Mindanao & Grand Naine & + & + \\
\hline
\end{tabular}


Table 3. PCR-based Race 4 and TR4 identification of Luzon Foc isolates using primers Foc-1/Foc-2 and FocTR4-F/FocTR4-R.

\begin{tabular}{|c|c|c|c|c|c|}
\hline \multicolumn{2}{|c|}{ Isolate } & \multicolumn{2}{|l|}{ Description } & \multicolumn{2}{|c|}{ PCR-Detection ${ }^{1}$} \\
\hline 55 & $1213=2$ & Mindanao & Grand Naine & + & + \\
\hline 56 & 1B & Puyod, Lasang & Grand Naine & + & + \\
\hline 57 & $1 \mathrm{C}$ & Dakudao, Panabo & Lakatan & + & + \\
\hline 58 & $1 G$ & Bancud, Tagum & GCTCV 219 & + & + \\
\hline 59 & $1 \mathrm{I}$ & Puyod, Lasang & GCTCV 219 & + & + \\
\hline 60 & $1 Q$ & GEA, New Corella & Grand Naine & + & + \\
\hline 61 & $2 \mathrm{G}$ & Lapiz, Sto Tomas & Grand Naine & + & + \\
\hline 62 & $2 \mathrm{~K}$ & Fabian, Sto. Tomas & Lakatan & + & + \\
\hline 63 & $3 \mathrm{~A}$ & Mauro, Calinan & Grand Naine & + & + \\
\hline 64 & $3 \mathrm{~J}$ & Lupida, Guiangan, Calinan & Grand Naine & + & + \\
\hline 65 & $3 \mathrm{M}$ & Aweng, Farm, Bunawan & Grand Naine & + & + \\
\hline 66 & $3 R$ & CFAR BEMCO, Carmen, D. Del Norte & Grand Naine & + & + \\
\hline 67 & $00-1$ & $\begin{array}{l}\text { Tangub City, San Vicente, } \\
\text { Misamis Occidental }\end{array}$ & Cardava & - & + \\
\hline 68 & 76R1 & Mindanao & Unknown & - & - \\
\hline 69 & $80 \mathrm{~A}$ & Mindanao & Grand Naine & - & - \\
\hline 70 & $88 \mathrm{~A}$ & Mindanao & Grand Naine & - & - \\
\hline 71 & $88 \mathrm{~B}$ & Mindanao & Grand Naine & - & - \\
\hline 72 & $88 \mathrm{C}$ & Mindanao & Grand Naine & - & - \\
\hline 73 & $88 \mathrm{D}$ & Mindanao & Grand Naine & - & - \\
\hline 74 & $89 \mathrm{~A}$ & Mindanao & Grand Naine & - & - \\
\hline 75 & $89 B$ & Mindanao & Grand Naine & - & - \\
\hline 76 & $89 \mathrm{C}$ & Mindanao & Grand Naine & - & - \\
\hline 77 & 89D & Mindanao & Grand Naine & - & - \\
\hline
\end{tabular}

${ }^{1}$ Symbols + indicates positive and - negative specific primer amplification. Numbers 56-77 isolates are from Mindanao analyzed by de la Cueva et al. [6].

The results obtained in this study suggest the occurrence of Race 4 in Luzon. Due to the high variation obtained in fingerprinting analyses, our results support the theory of co-evolution where Foc evolved with the edible banana originating in South East Asia. The use of molecular techniques as A more reliable method to detect Race 4 has been widely accepted, and used in the case of reporting the occurrence of TR4 in Indonesia [52] and first report of TR4 outside South East Asia [53]. The race system classification initially helped to discriminate populations, but is already outdated and leads to erroneous conclusions, hampering decision making. For instance, positive results by PCR identification were obtained from isolates in areas where ST4 has not been reported such as in Brazil, Costa Rica, Honduras and the USA [27]. This implies that an isolate can be considered ST4 in areas where it causes symptoms in Cavendish bananas and as Race 1 in areas where it does not affect Cavendish such as in tropical areas in Brazil, Costa Rica and Honduras.

\subsection{Fingerprinting Analyses}

A total of 22 Foc isolates from Mindanao and two TR4 positive checks were analyzed using ERIC-PCR and M13 primer set. Only 58 isolates were subjected to REP analysis. Standardized DNA at $50 \mathrm{ng} / \mu \mathrm{L}$ was used in the different fingerprinting.

\subsection{ERIC-PCR}

ERIC-PCR in Luzon isolates alone amplified a total of 22 banding patterns ranging from 200-5000 bp. Reproducible 3-12 bands of varying intensities were consistent in two analyses conducted. UPGMA cluster analysis showed $19-100 \%$ similarity on tested isolates. Two distinct clades were formed, regardless of banana cultivars and geographic distribution. Major bands include 450, 350 and $300 \mathrm{bp}$ for clade A, while 400 and $100 \mathrm{bp}$ are common in clade B (Figure 3). 


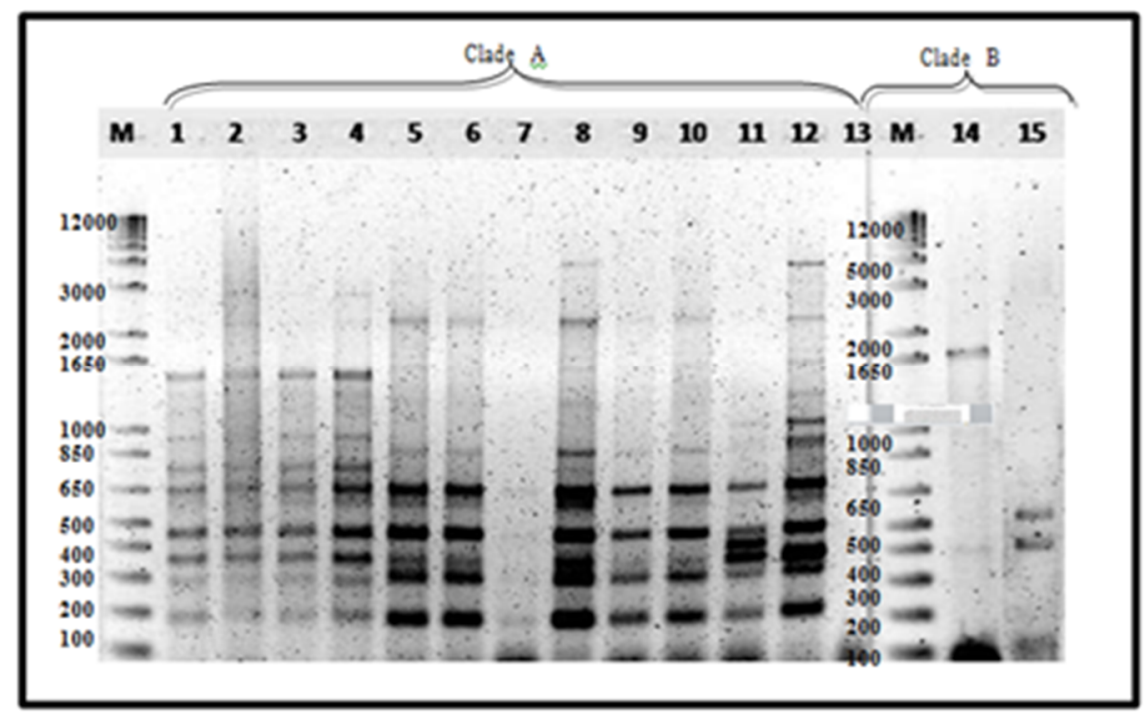

Figure 3. ERIC-PCR amplification of 15 representative Foc isolates. Lane 1, 16B1; 2, 18B3a; 3, 19B2; 4, 24B1; 5, 1Q; 6, 2K; 7, 2G; 8, 3A; 9, 80A; 10, 1213-1; 11, 88A; 12, 89A; 14, 43B2; 15, 43A. Luzon isolates-lanes 1-4, 14-15; Mindanao isolates-lanes 5-12.

Mindanao and Luzon isolates generated a similarity value of $16-100 \%$ with a total of 22 banding patterns. Two clades were also formed with all Mindanao isolates grouped in clade A having high similarity value at $40-100 \%$, except isolate 3 J (Figure 4). The major banding pattern at 650, 450, 300 and $200 \mathrm{bp}$ with an insert at $350 \mathrm{bp}$ is a characteristic feature of Mindanao isolates. Isolates tested positive to Race 4 using primer designed by Lin et al. [31] were categorized in both clades where isolates 24A2a, 31A, 32A, 94A, 101A2, 101B2, 102D1, 104B1,106B1 and 48A1 were under clade A, while only isolate43B2 in clade B. Using ERIC-PCR analyses, Leong et al. [54] likewise categorized isolates from Malaysia and Indonesia into two distinct clades. Furthermore, the suitability of ERIC-PCR was emphasized due to higher variation as compared to PCR-RFLP of ITS+ 5.8S regions [18]. The whole genome is analyzed with ERIC-PCR, as compared to RFLP, which involves specific regions only, giving more information in analyzing closely related species [20,55].

All isolates tested successfully generated ERIC banding patterns indicating that repetitive elements could be found in abundance in the FOC genome, consistent with the studies conducted by Leong et al. [56] where 29 banding patterns were observed ranging from 100-3750 and Edel [20] with 19 banding patterns ranging from $100-4000 \mathrm{bp}$. 


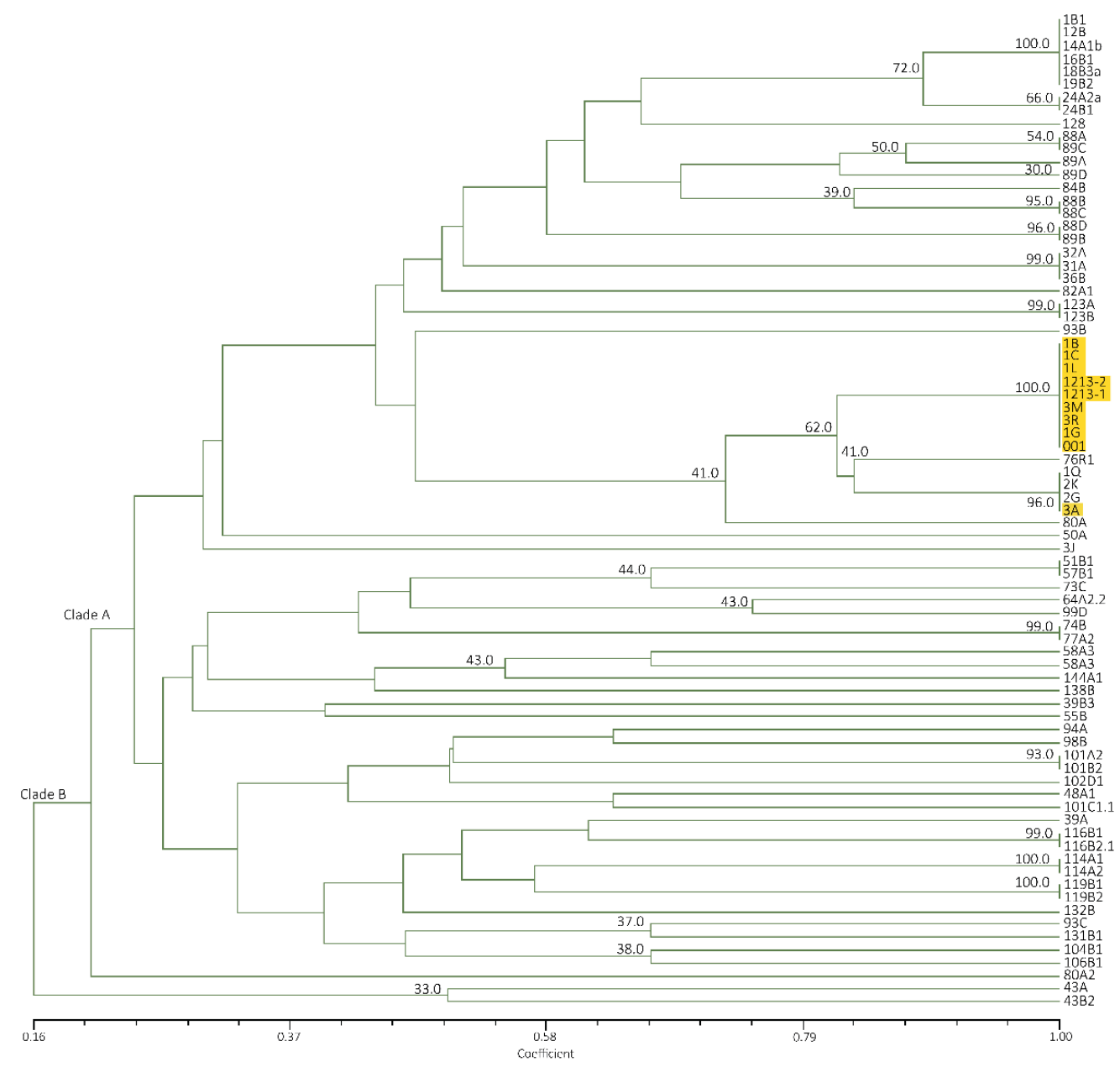

Figure 4. Dendrogram from UPGMA cluster analysis using Jaccard Similarity Coefficient of representative Foc isolates from Luzon and Mindanao based on ERIC-PCR. TR4 isolates are highlighted in yellow.

\subsection{RAPD-PCR Using M13 Primer}

The use of M13 primer is considered as RAPD-PCR, since no preliminary information on the target sequence is required. Foc being a haploid asexual pathogen can be effectively analyzed using arbitrary primer techniques such as RAPD and DNA amplification fingerprinting (DAF) [42]. As enumerated by Bentley [57], additional advantages of using RAPD-PCR to study genetic variation include the following: (1) it does not involve the use of cloning, sequencing or radioactively labelled probes, (2) primers can be designed for various levels of differentiation, (3) it is applicable to large numbers of isolates and (4) it analyses variation at more than one locus. Using M13 primer, eighteen 18 banding patterns were observed ranging from $2800 \mathrm{bp}$ to $100 \mathrm{bp}$ (Figure 5).

UPGMA cluster analysis on Luzon isolates revealed a similarity of $18-100 \%$ forming two clades. With Mindanao isolates, total of 22 banding patterns of the same range as the latter were observed forming two clades as well with similarity value of $14-100 \%$ (Figure 6). Consistent in clade A is the presence of $900 \mathrm{bp}$ major band, while 1000 and $850 \mathrm{bp}$ bands are consistent with majority of isolates belonging to clade B. All Mindanao isolates were grouped together in clade A, consistent with ERIC-PCR analyses where a distinct feature includes the presence of a $450 \mathrm{bp}$ very distinct band and $500 \mathrm{bp}$ faint band. Considering ten isolates that were positive to Race 4 using Foc/Foc2 primers, clade A includes 24A2a, 31A, 32A, 94A, 101A2, 101B2, 102D1 and 104B1, while clade B include isolates 43B2 and 48A1. 


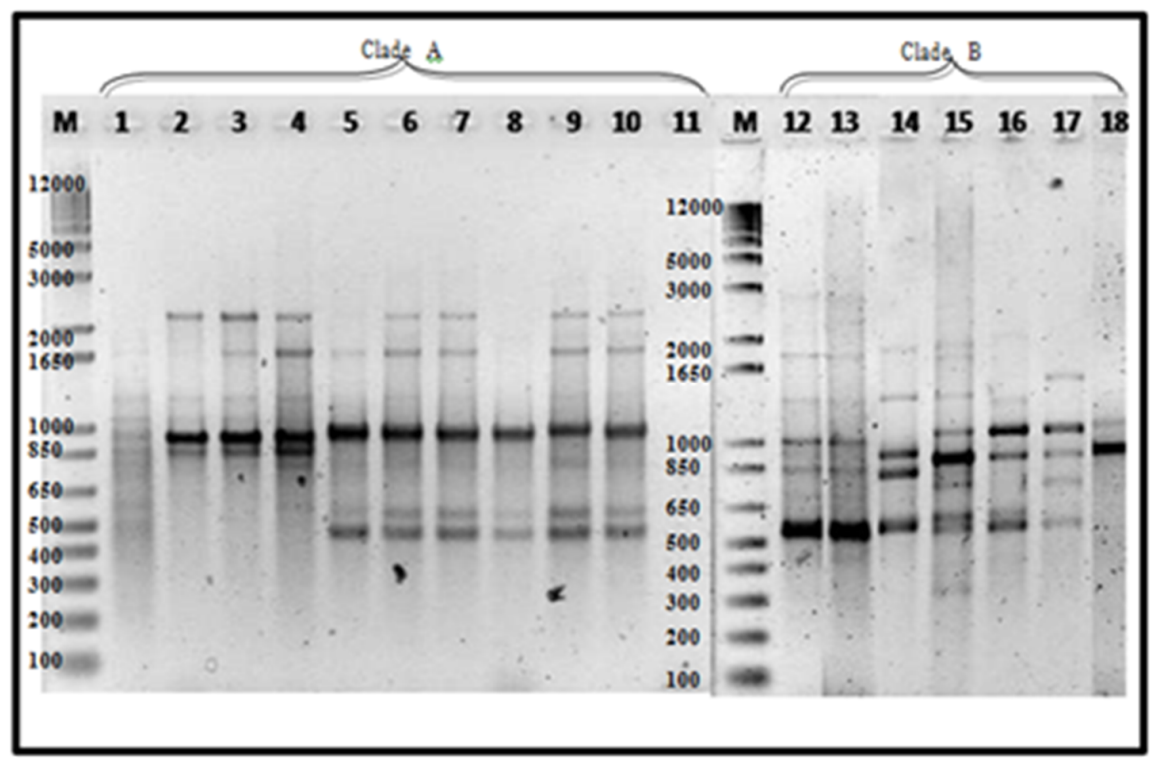

Figure 5. M13 amplification of 17 representative Foc isolates. Lane 1, 1B1; 2, 12B; 3,14A1b; 4, 16B1; 5, 1B; 6, 1C; 7, 2G; 8, 3A; 9, 76R1; 10, 1213-1 (positivecheck); 11, DEPC water; 12, 51B1; 13, 57B1; 14, 43B2; 15, 50A; 16, 74B; 17,77A2; 18, 48A1. Mindanao isolates-lanes 5-10; Luzon isolates-lanes 1-4, 12-18.

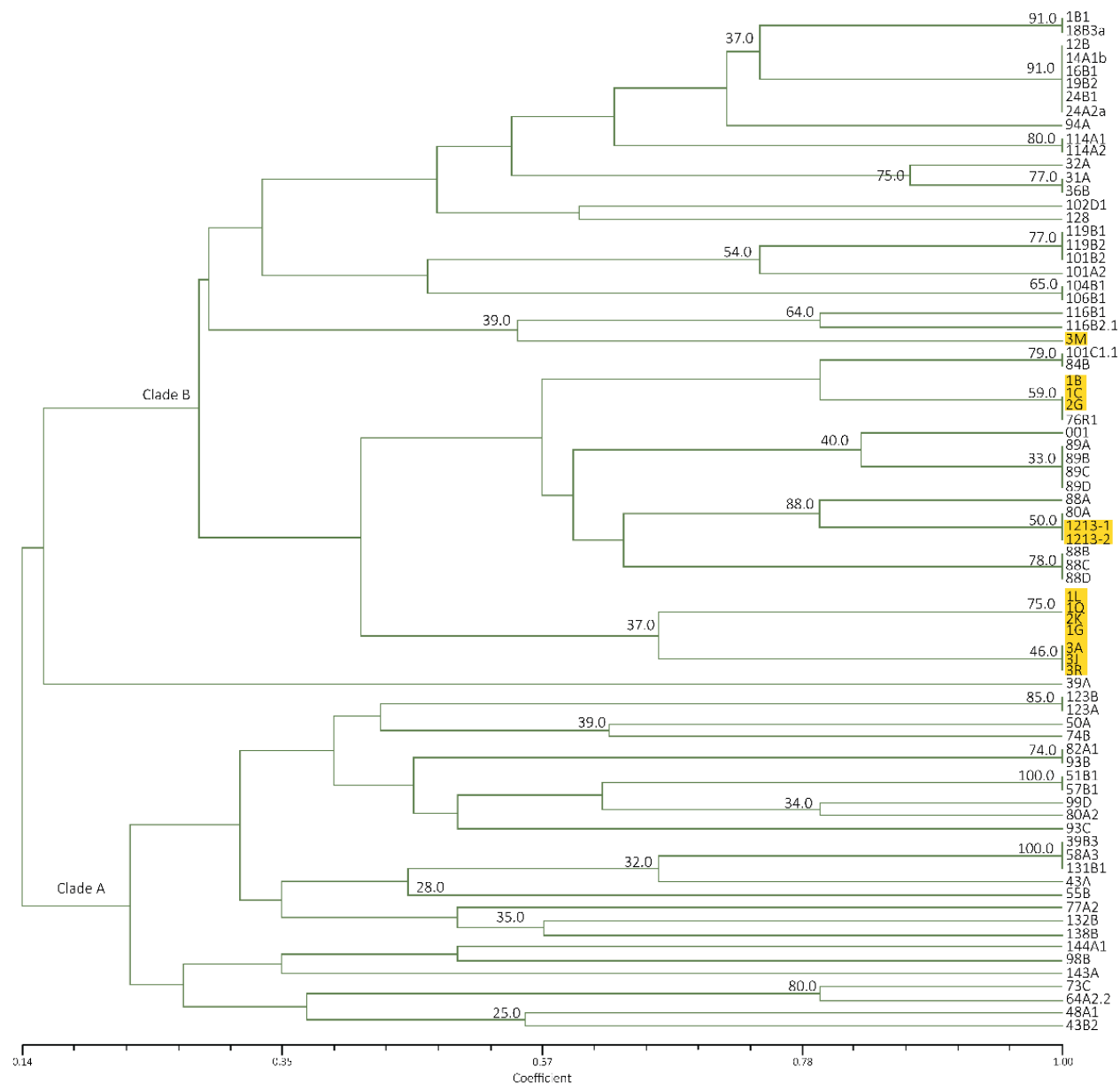

Figure 6. Dendrogram generated from UPGMA cluster analysis using Jaccard Similarity Coefficient of representative Foc isolates from Luzon and Mindanao based on M13 analyses. TR4 isolates are highlighted in yellow. 


\subsection{REP-PCR}

Not all isolates generated reproducible bands for REP primer set, thus from the 77 isolates analyzed for M13 and ERIC, 58 isolates, 40 from Luzon and 18 from Mindanao including two positive checks were analyzed using REP-PCR. A total of 22 banding patterns ranging from $5000 \mathrm{bp}$ to $100 \mathrm{bp}$ were formed with varying intensities (Figure 7).

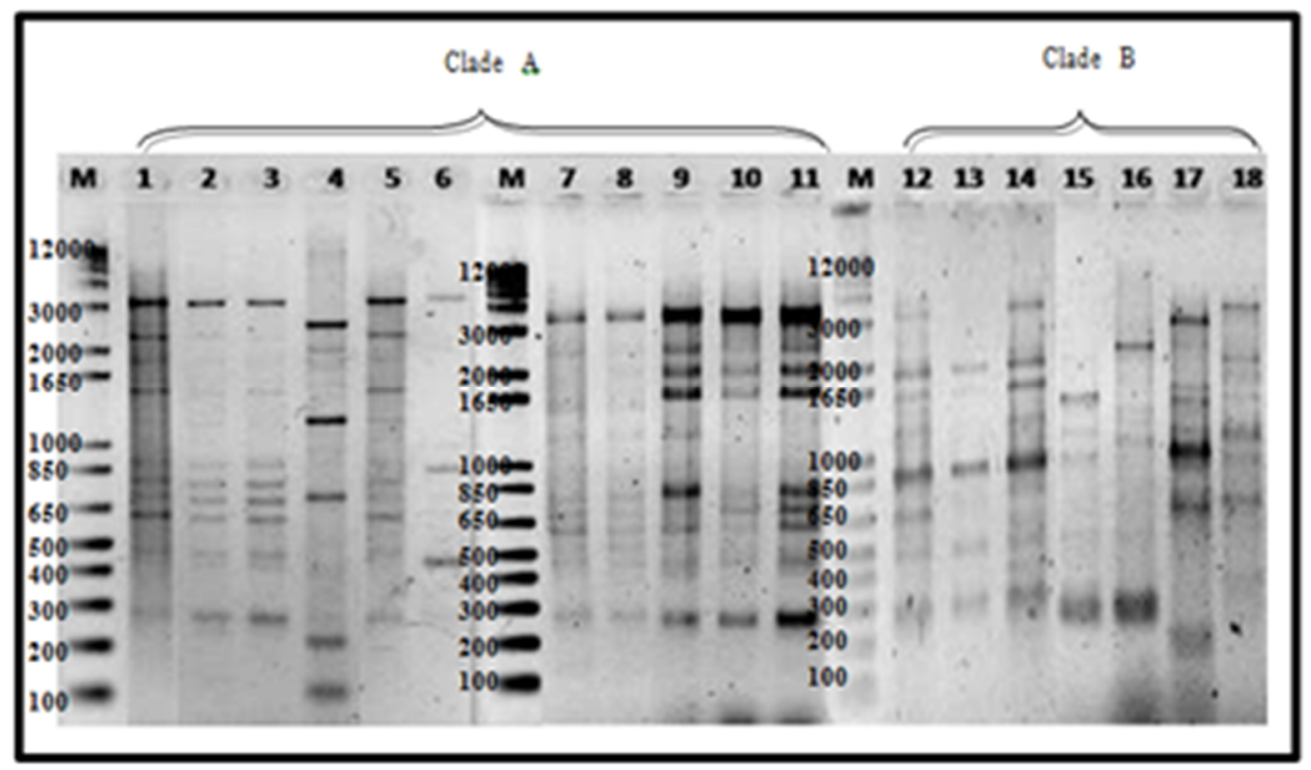

Figure 7. REP amplification of 18 representative Foc isolates: Lane 1, 1G; 2, 2G;3, 3A; 4, 1L; 5, 3R; 6, 001A; 7, DEPC water; 8, 80A; 9, 1213-1 (positive check); 10, 88B; 11, 88C; 12, 88D; 12, 1B1; 13, 12B; 14,14A1b; 15,43A; 16, 43B2; 17, 51B1; 18, 57B1. Mindanao isolates-Lanes 1 to 12, Luzon isolates-Lanes 12-18. The ladder size is shown in number of base pairs.

Considering Luzon isolates only, UPGMA cluster analysis gave similarity of 14-100\% forming two groups, which is in consistent with M13 primer except isolates 116B1 and 116B2.1. With Mindanao isolates, similarity ranged from $17-100 \%$ with the same total banding patterns forming two clades as well (Figure 8). Consistent in clade A was the presence of approximately 3000 and 900 bp major bands, while clade B has no consistent major bands, but the presence of $1200 \mathrm{bp}$ was observed with varying intensities. Unique pattern for Mindanao isolates, including positive check is the presence of three bands at 700, 650 and $500 \mathrm{bp}$ under clade A, except 3J, 1B and 1L which was categorized under clade B. Grouping of isolates that were positive to Race 4 is consistent with M13 primer where majority of the isolates belonged to clade $\mathrm{A}$ and only isolates 43B2 and 48A1 were under clade B. 


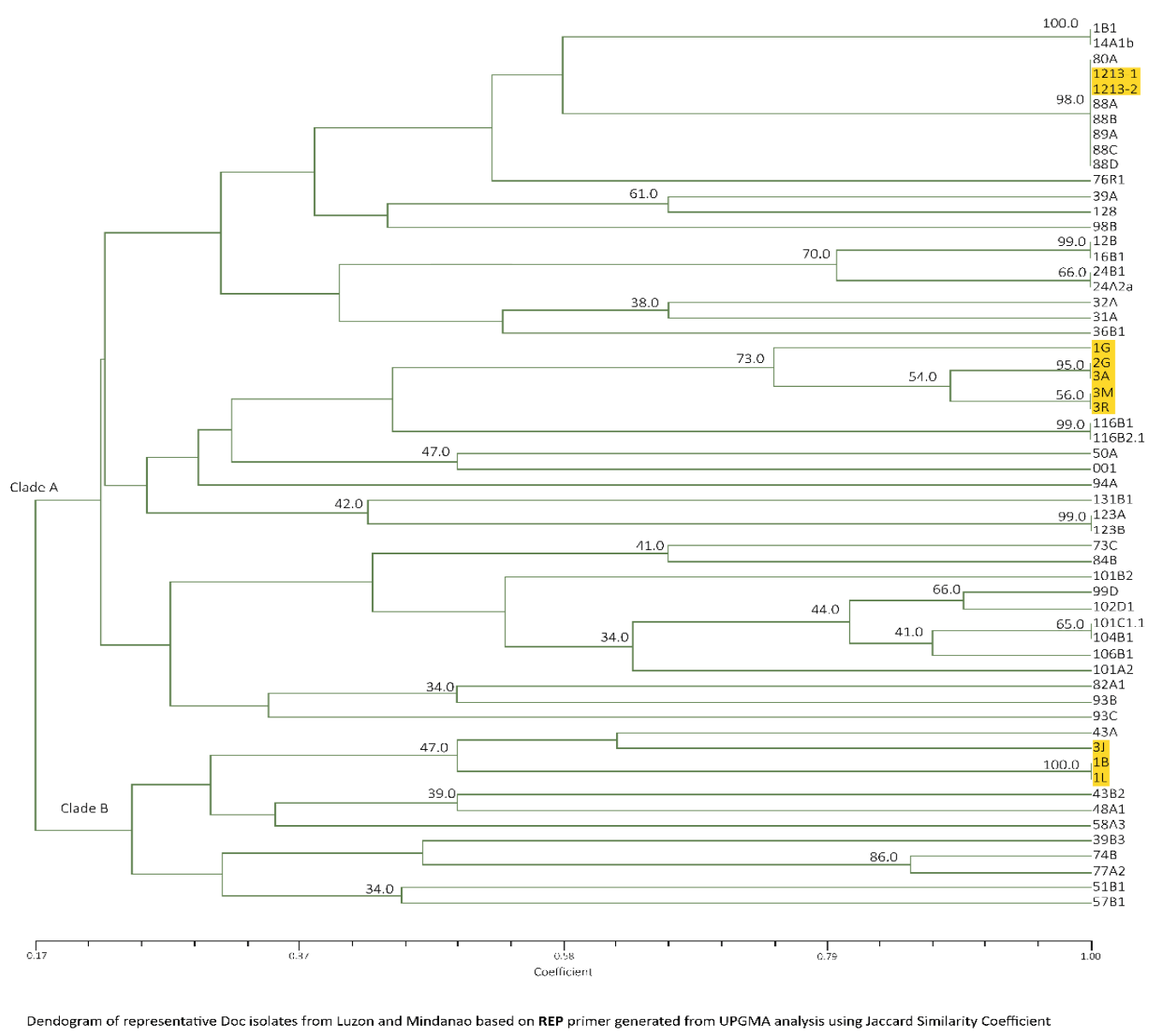

Figure 8. Dendrogram of representative Foc isolates from Luzon and Mindanao based on REP primer generated from UPGMA cluster analysis using Jaccard Similarity Coefficient. TR4 isolates are highlighted in yellow.

\subsection{BOX Elements}

Using BOX primer, very few banding patterns were obtained; some isolates did not even produce a single band. Gradient to optimize PCR conditions as well as variation on the concentration of mixtures had been made, but were not successful. The results suggest presence of BOX elements in Foc, but due to greater sequence conservation, lesser banding patterns were observed (data not shown).

Collectively, results suggest low variability among Mindanao isolates as compared from Luzon collection considering similarity values in all primers used, which can be attributed to intensive monoculture practice in banana plantains. Furthermore, there were particularly no trends with regard to what cultivar were Foc isolated from as well as geographical location. The consistency of having two clades in all analyses is in agreement with the study of Fourie et al. [18], where Philippines isolates included in the study were categorized under clade A, while from Latundan was categorized under clade B. Results indicate high variability among Foc population in the Philippines as compared to genetic variability studies of the pathogen in other countries [58] supporting further the theory of co-evolution by Stover [7], where Foc is believed to have co-evolved with edible bananas and their wild diploid progenitors originating in South East Asia.

Among the three molecular markers used ERIC-PCR was the most informative and predictive, because the TR4 isolates belonged to one group, outperforming RAPD-PCR and REP primers where they were spread apart and at times some TR4 isolates were absent. ERIC-PCR is designed to target repetitive sequences that are highly conserved in the genome. The position of these elements varies from species to species, but is usually 126 bp long, highly conserved at the nucleotide level, and include 
a central core inverted repeat [59]. In this technique, a band pattern is obtained by amplification of genomic DNA located between ERIC elements or between ERIC elements and other repetitive DNA sequences. Characterization of Foc isolates from Malaysia using ERIC-PCR suggested low variability indicating close genetic relatedness regardless of cultivars and area of collection [54]. We did not conduct combined analysis of the three markers as RAPD-PCR and REP were less informative, which could only weaken the cluster grouping.

When breeding for resistance, variability studies have been the primary focus of research, particularly for economically important diseases such as Panama disease. Race determination as a phenotypic marker is based on the capacity to infect different banana cultivars under field conditions, where Race 1 infects Gros Michel, Silk, Apple, Lady Finger and Latundan, Race 2 attacks Bluggoe bananas and Race 4 attacks all cultivars susceptible to Foc Races 1 and 2 as well as Cavendish bananas. Race 4 is further classified into ST4 and TR4 to differentiate Foc causing disease to Cavendish in the subtropics and tropics, respectively. However, while ST4 isolates cause disease in Cavendish in the subtropics, mainly when plants are exposed to abiotic stress, TR4 isolates are pathogenic under both tropical and subtropical conditions [15]. The above mentioned race concept complicate identification, and does not capture genetic variation. Therefore, neutral DNA-based technique would be more suitable in analyzing genetic variation within and between Foc populations.

Author Contributions: Conceptualization, C.J.R.C.; Data curation, K.G.I.A.-H.; Formal analysis, K.G.I.A.-H. and C.J.R.C.; Investigation, K.G.I.A.-H. and F.M.d.l.C.; Methodology, K.G.I.A.-H.; Project administration, F.M.d.l.C.; Supervision, F.M.d.I.C. and C.J.R.C.; Writing-original draft, K.G.I.A.-H.; Writing-review \& editing, K.G.I.A.-H. and C.J.R.C. All authors have read and agreed to the published version of the manuscript.

Funding: The APC was funded by the University of Göttingen, Germany.

Acknowledgments: We thank Nels Hansen, Chair of the Department of Applied Plant Science, Brigham Young University Idaho, USA for editing English language and Ria Alejar, graphic artist for improving the resolution of the UPGMA cluster figures.

Conflicts of Interest: The authors declare no conflicts of interest.

\section{References}

1. Lassois, L.; Haissan Jijakli, M.; Chillet, M.; De Lapeyre, L. De Bellaire Crown Rot of Bananas: Preharvest Factors Involved in Postharvest Disease Development and Integrated Control Methods. Plant Dis. 2010, 94, 648-659. [CrossRef]

2. Aurore, G.; Parfai, B.; Fahrasmane, L. Bananas, raw materials for making processed food products. Trends Food Sci. Technol. 2009, 20, 78-91. [CrossRef]

3. Calderon, R.P.; Rola, A.C. Assessing Benefits and Cost of Commercial Banana Production in the Philippines; Working Paper 03; Institute of Strategic Planning and Policy Studies (ISPPS), College of Public Affairs, University of the Philippines Los Banos, College Laguna: Los Baños, Philippines, 2003.

4. Philippine Center for Post-Harvest Development and Mechanization (PHILMECH). 2012. Available online: http://www.philmech.gov.ph/phindustry/banana.htm (accessed on 27 December 2019).

5. Bureau of Agricultural Statistics (BAS). 2012. Available online: http//www.bas.gov.ph (accessed on 27 December 2019).

6. De la Cueva, F.M.; Silva, F.F.M.; Molina, A. Assessment of Musa genetic resources for their host reaction to Fusarium oxysporum f. sp. cubense Tropical Race 4 (TR4), towards understanding the genetic base of host-pathogen interactions. 2013; Unpublished Annual Report.

7. Stover, R.H. Fusarial Wilt (Panama Disease) of Bananas and Other Musa Species; Commonwealth Mycological Institute: Kew, UK, 1962.

8. Hwang, S.H.; Ko, W.H. Cavendish banana cultivars resistant to Fusarium wilt acquired through somaclonal variation in Taiwan. Plant Dis. 2004, 88, 580-588. [CrossRef] [PubMed]

9. Pegg, K.G.; Moore, N.Y.; Sorensen, S. Fusarium wilt in the Asian Pacific region. In Proceedings of the International Symposium Recent Developments Banana Cultivation Tech; Valmayor, R.V., Hwang, S.C., Ploetz, R.C., Lee, S.W., Roa, N.V., Eds.; International Network for the Improvement of Banana and Plantain/The Asia and Pacific Network (INIBAP/ASPNET): Los Banos, Philippines, 1993; pp. 255-269. 
10. Pegg, K.G.; Shivas, R.G.; Moore, N.Y.; Bentley, S. Characterization of a unique population of Fusarium oxysporum f. sp. cubense causing Fusarium wilt in Cavendish bananas at Carnavon, Western Australia. Aust. J. Agric. Res. 1995, 46, 167-178. [CrossRef]

11. Ploetz, R.C.; Pegg, K.G. Fusarium Wilt. In Diseases of Banana, Abaca and Enset; Jones, D.R., Ed.; CABI Publishing: Wallingford, UK, 2000; pp. 143-149.

12. Stover, R.H. Fusarium Wilt of Banana: Some History and Current Status of the Disease; Ploetz, R.C., Ed.; Fusarium Wilt of Banana; APS Press: St. Paul, MN, USA, 1990; pp. 1-7.

13. Ploetz, R.C. Population Biology of Fusarium Oxysporum f.sp. Cubense; Ploetz, R.C., Ed.; Fusarium Wilt of Banana; APS Press: St. Paul, MN, USA, 1990; pp. 63-67.

14. Viljoen, A. The status of Fusarium wilt (Panama disease) of banana in South Africa. S. Afr. J. Sci. 2002, 98, 341-344.

15. Buddenhagen, L.W. Understanding strain diversity in Fusarium oxysporum f. sp. cubense and history of introduction of 'tropical race 4' to better manage banana production. ISHS Acta Hortic. 2009, 828, 193-204. [CrossRef]

16. Mostert, D.; Molina, A.B.; Daniells, J.; Fourie, G.; Hermanto, C.; Chao, C.P.; Fabregar, E.; Sinohin, V.G.; Masdek, N.; Thangavelu, R.; et al. The distribution and host range of the banana Fusarium wilt fungus, Fusarium oxysporum f. sp. cubense, in Asia. PLoS ONE 2017, 12, e0181630. [CrossRef]

17. Solpot, T.C.; Pangga, I.R.; Baconguis, R.D.T.; Cumagun, C.J.R. Occurrence of Fusarium oxysporum f. sp. cubense Tropical Race 4 and other genotypes in banana in South-Central Philippines. Philipp. Agric. Sci. 2016, 99, 370-378.

18. Fourie, G.; Steenkamp, E.T.; Gordon, T.R.; Viljoen, A. Evolutionary Relationships among the Fusarium oxysporum f. sp. cubense Vegetative Compatibility Groups. Appl. Environ. Microbiol. 2009, 75, 4770-4781. [CrossRef]

19. Ryskov, A.P.; Jincharadze, A.G.; Prosnyak, M.I.; Ivanov, P.I.; Limborska, S.A. M13 phage DNA as a universal marker for DNA fingerprinting of animals, plants and microorganisms. FEBS Lett. 1988, 233, 388-392. [CrossRef]

20. Edel, V.; Steinberg, C.; Avelange, I.; Laguerre, G.; Alabouvette, C. Comparison of three molecular methods for the characterization of Fusarium oxysporum strains. Phytopathology 1995, 85, 579-585. [CrossRef]

21. George, M.C.; Nelson, R.J.; Zeigler, R.S.; Leung, H. Rapid population analysis of Magnaporthe grisea by using rep-PCR and endogenous repetitive DNA sequences. Phytopathology 1997, 88, 223-229. [CrossRef] [PubMed]

22. Versalovic, J.; Koeuth, T.; Lupski, R.J. Distribution of repetitive DNA sequences in eubacteria and application to fingerprinting of bacterial genomes. Nucleic Acids Res. 1991, 19, 6823-6831. [CrossRef] [PubMed]

23. Nirenberg, H. Untersuchungenueber die morphologische und biologischedifferenzierung in der Fusarium-Sektion Liseola. Mitt. Biol. Bundesanst. Land-u. Forstwirtsch. Berlin-Dahlem 1976, 169, 1-117.

24. Burgess, L.W.; Summerell, B.A.; Bullock, S.; Golt, K.; Backhouse, D. Laboratory Guide to the Identification of Fusarium research.Fusarium Research Laboratory; Department of Crop Sciences, University of Sydney and Royal Botanic Gardens: Sydney, Australia, 1994; pp. 13-14.

25. Nelson, P.E.; Toussoun, T.A.; Marasas, W.F.O. Fusarium Species. An Illustrated Manual for Identification; Pennsylvania State University Press: University Park, PA, USA, 1983; p. 193.

26. Leslie, J.F.; Summerell, B.A. The Fusarium Laboratory Manual; Blackwell: Ames, IA, USA, 2006; p. 388.

27. Dita, M.A.; Waalwijk, C.; Buddenhagen, I.W.; Souza, M.T.; Kema, G.J.H. A molecular diagnostic for tropical race 4 of the banana Fusarium wilt pathogen. Plant Pathol. 2010, 59, 348-357. [CrossRef]

28. Carlier, J.; Waele, D.; Escalant, J. Global Evaluation of Musa Germplasm for Resistance to Fusarium wilt, Mycosphaerella Leaf Spot Diseases and Nematodes; INIBAP; Bioversity International: Rome, Italy, 2002.

29. Moller, E.M.; Bahnweig, G.G.; Sandermann, H.; Geiger, H.H. A simple and efficient protocol for the isolation of high molecular weight DNA from filamentous fungi, fruiting bodies and infected plant tissues. Nucleic Acids Res. 1993, 20, 6115-6116. [CrossRef]

30. Molina, A.; Fabregar, E.; Sinohin, V.G.; Herradura, V.L.; Fourie, G.; Viljoen, A. Confirmation of tropical race 4 of Fusarium oxysporum f. sp. cubense infecting Cavendish bananas in the Philippines. In Proceedings of the Centennial Meeting of the American Phytopathological Society, Minneapolis, MA, USA, 26-30 July 2008.

31. Lin, Y.H.; Chang, J.Y.; Liu, E.T.; Chao, C.P.; Huang, J.W.; Chang, P.F.L. Development of a molecular marker for specific detection of Fusarium oxysporum f. sp. cubense race 4. Eur. J. Plant Pathol. 2009, 123, 353-365. [CrossRef] 
32. Bridge, P.D.; Pearce, D.A.; Rivera, A.; Rutherford, M.A. VNTR derived oligonucleotides as PCR primers for population studies in filamentous fungi. Lett. Appl. Microbiol. 1997, 24, 426-430. [CrossRef]

33. Rohlf, F.J. NTSYS-pc: Numerical Taxonomy and Multivariate Analysis System; Version 2.0; Exeter Software: New York, NY, USA, 1993.

34. Bentley, S.K.; Pegg, G.; Dale, J.L. Optimization of RAPD-PCR fingerprinting to analyse genetic variation within populations of Fusarium oxysporum f.sp. cubense. J. Phytopathol. 1994, 142, 64-78. [CrossRef]

35. Yap, I.V.; Nelson, R.J. Winboot: A Program Performing Bootsrap Analysis of Binary Data to Determine the Confidence Limits of UPGMA-Based Dendograms; International Rice Research Institute: Manila, Philippines, 1996.

36. Groenewald, S.; Van den Berg, N.; Marasas, W.F.O.; Viljoen, A. Biological, physiological and pathogenic variation in a genetically homogenous population of Fusarium oxysporum f.sp. cubense. Australas. Plant Pathol. 2006, 35, 401-409. [CrossRef]

37. Roncero, M.E.G.; Hera, C.; Ruiz-Rubio, M.; Maceira, F.I.G.; Madrid, M.P. Fusarium as a model for studying virulence in soilborne plant pathogens. Physiol. Mol. Plant Pathol. 2003, 62, 87-98. [CrossRef]

38. Lievens, B.; Rep, M.; Thomma, B. Recent developments in the molecular discrimination of formae speciales of Fusarium oxysporum. Pest Manag. Sci. 2008, 64, 781-788. [CrossRef] [PubMed]

39. Gao, H.; Beckman, C.H.; Mueller, W.C. The rate of vascular colonization as a measure of the genotypic interaction between various cultivars of tomato and various formae specials of Fusarium oxysporum. Physiol. Mol. Plant Pathol. 1995, 47, 29-43. [CrossRef]

40. Gordon, T.R.; Okamoto, D. Population structure and the relationship between pathogenic and non-pathogenic strains of Fusarium oxysporum. Phytopathology 1992, 82, 73-77. [CrossRef]

41. Appel, D.J.; Gordon, T.R. Local and regional variation in populations of Fusarium oxysporum from agricultural field soils. Phytopathology 1994, 84, 787-791. [CrossRef]

42. Bentley, S.K.G.; Pegg, N.; Moore, Y.; Davis, R.D.; Buddenhagen, L.W. Genetic Variation Among Vegetative Compatibility Groups of Fusarium oxysporum f. sp. cubense Analyzed by DNA Fingerprinting. Phytopathology 1998, 88, 1283-1293. [CrossRef]

43. Groenewald, S.; Van Den Berg, N.; Marasas, W.; Viljoen, A. The application of high-throughput AFLP's in assessing genetic diversity in Fusarium oxysporum f. sp. cubense. Mycol. Res. 2006, 110, 297-305. [CrossRef]

44. Smith, L.J.; Smith, M.K.; Tree, D.; O'Keefee, D.; Galea, V.J. Development of a small-plant bioassay to assess banana grown from tissue culture for consistent infection by Fusarium oxysporum f. sp. cubense. Australas. Plant Pathol. 2008, 37, 171-179. [CrossRef]

45. Muiru, W.M.; Koopmann, B.; Tiedemann, A.V.; Mutitu, E.W.; Kimenju, J.W. Use of Repetitive Extragenic Palindromic (REP), Enterobacterial Repetitive Intergenic Consensus (ERIC) and BOX sequences to fingerprint Exserohilum turcicum isolates. J. Appl. Biosci. 2010, 30, 1828-1838.

46. Correll, J.C. The relationship between formae speciales, races and vegetative compatibility groups in Fusarium oxysporum. Phytopathology 1991, 81, 1061-1064.

47. Davis, R.D.; Moore, N.Y.; Kochman, J.K. Characterization of a population of Fusarium oxysporum f.sp. vasinfectum causing wilt of cotton. Aust. J. Agric. Res. 1996, 47, 1143-1156. [CrossRef]

48. Ploetz, R.C. Fusarium wilt of banana is caused by several pathogens referred to as Fusarium oxysporum f. sp. cubense. Phytopathology 2006, 96, 653-656. [CrossRef] [PubMed]

49. Pegg, K.G.; Moore, N.Y.; Bentley, S. Fusarium wilt of banana in Australia: A review. Aust. J. Agric. Res. 1996, 47, 637-650. [CrossRef]

50. Su, E.J.; Hwang, S.C.; Ko, W.H. Fusarial wilt of Cavendish Bananas in Taiwan. Plant Dis. 1986, 70, 814-818.

51. Bentley, S.; Pattemore, J.; Moore, N.Y. Foc Tropical Race 4 Diagnostic Manual. Cooperative Research Centre for Tropical Plant Protection; Queensland University: St. Lucia, Australia, 2003.

52. Wibowo, A.; Subandiyah, S.; Sumardiyono, C.; Sulistyowati, L.; Taylor, P.; Fegan, M. Occurrence of Tropical Race 4 of Fusarium oxysporum f. sp. cubense in Indonesia. Plant Pathol. J. 2011, 27, 280-284. [CrossRef]

53. Garcia-Bastidas, F.; Ordóñez, N. First Report of Fusarium oxysporum f. sp. cubense Tropical Race 4 associated with Panama Disease of banana outside Southeast Asia. Plant Dis. 2014, 98, 694. [CrossRef]

54. Leong, S.K.; Latiffah, Z.; Baharuddin, S. Molecular characterization of Fusarium oxysporum f. Sp. cubense of banana. Am. J. Appl. Sci. 2009, 6, 1301-1307. [CrossRef]

55. Godoy, P.; Cano, J.; Gené, J.; Guarro, J.; Höfling-Lima, A.L.; Colombo, A.L. Genotyping of 44 isolates of Fusarium solani, the main agent of fungal keratitis in Brazil. J. Clin. Microbiol. 2004, 42, 4494-4497. [CrossRef] 
56. Leong, S.K.; Latiffah, Z.; Baharuddin, S. Genetic diversity of Fusarium oxysporum f. sp. cubense isolates from Malaysia. Afr. J. Microbiol. Res. 2010, 4, 1026-1037.

57. Bentley, S.; Pegg, K.G.; Dale, J.L. Genetic variation among a world-wide collection of isolates of Fusarium oxysporum f. sp. cubense analysed by RAPD-PCR fingerprinting. Mycol. Res. 1995, 99, 1378-1384. [CrossRef]

58. Visser, M.; Gordon, T.; Fourie, G.; Viljoen, A. Characterisation of South African isolates of Fusarium oxysporum f.sp. cubense from Cavendish bananas. S. Afr. J. Sci. 2010, 106, 1-6. [CrossRef]

59. Zulkifli, Y.; Alitheen, N.B.; Son, R.; Raha, A.R.; Samuel, L.; Yeap, S.K.; Nishibuchi, M. Random amplified polymorphic DNA-PCR and ERIC PCR analysis on Vibrio parahaemolyticus isolated from cockles in Padang, Indonesia. Int. Food Res. J. 2009, 16, 141-150.

(C) 2019 by the authors. Licensee MDPI, Basel, Switzerland. This article is an open access article distributed under the terms and conditions of the Creative Commons Attribution (CC BY) license (http://creativecommons.org/licenses/by/4.0/). 